\title{
Spatial Variation in Groundwater Types in the Mt. Karang (West Java, Indonesia) Volcanic Aquifer System Based on Hydro-Chemical and Stable Isotope $\left(\delta \mathrm{D}\right.$ and $\left.\delta^{18} \mathrm{O}\right)$ Analysis
}

\author{
Boy Yoseph CSS Syah Alam ${ }^{1,2}$, Ryuichi Itoi ${ }^{1}$, Sachihiro Taguchi ${ }^{3} \&$ Rie Yamashiro ${ }^{1}$ \\ ${ }^{1}$ Department of Earth Resources Engineering, Faculty of Engineering, Kyushu University, Fukuoka, Japan \\ ${ }^{2}$ Faculty of Geology, Padjadjaran University, Bandung, West Java, Indonesia \\ ${ }^{3}$ Faculty of Science, Fukuoka University, Fukuoka, Japan \\ Correspondence: Boy Yoseph CSS Syah Alam, Department of Earth Resources Engineering, Graduate School of \\ Engineering, Kyushu University, 744 Motooka Nishi-ku, Fukuoka 819-0395, Japan. Tel: 81-92-802-3345. \\ E-mail: boy_yoseph@mine.kyushu-u.ac.jp; boy_yosef@yahoo.com
}

Received: July 16, 2014

doi:10.5539/mas.v8n6p87
Accepted: August 8, 2014 Online Published: September 12, 2014

URL: http://dx.doi.org/10.5539/mas.v8n6p87

\begin{abstract}
On the island of Java, groundwater use has significantly increased because of population growth and industrial development. Mt. Karang (a volcano in West Java, Indonesia) has the potential to be a significant groundwater source. Samples were collected twice from springs, dug wells and rivers (rainy and dry seasons). We used information about the aquifer system, hydrogeological conditions and hydro-chemical data to investigate groundwater sources and their associated recharge processes. Chemical data showed that samples belonged to the $\mathrm{Ca}-\mathrm{Na}-\mathrm{HCO} 3$ type in both seasons. The dominant $\mathrm{Ca}^{2+}$ indicates that this water may have flowed through a rock formation composed of andesitic-basaltic rocks with Ca-plagioclase minerals. $\mathrm{HCO}_{3}{ }^{-}$originates from either infiltration of rain water that has been equilibrated with $\mathrm{CO}_{2}$ in the atmosphere, or from $\mathrm{CO} 2$ that has been generated by respiration of organic material. Several groundwater samples shows the isotopes values were lighter in the rainy season than in the dry season, which may indicate evaporation during infiltration in the recharge area. There are two types of water isotopically; one is relatively deep circulated water with consistent $\delta \mathrm{D}$ values, the other is of shallow circulated one affected by evaporation. We reconstructed a conceptual model of the groundwater flow systems and recharge mechanisms in Mt. Karang, based on hydrogeological, hydro-chemical and stable isotope data. This model will give an improved understanding of the region's hydrogeological condition.
\end{abstract}

Keywords: groundwater, hydro-chemical, stable isotopes, recharge mechanism and Mt. Karang

\section{Introduction}

On the island of Java, groundwater consumption has increased significantly because of population growth and industrial development. The groundwater is mostly used for domestic water supplies, agriculture (paddy fields) and industrial purposes (Adi, 2003).

The study area was on the north side of Mt. Karang, in Padarincang-Ciomas, Banten Province, Western Java, Indonesia (Figure 1a). There are two prominent volcanoes in the study area: Mt. Karang and Mt. Parakasak. The slopes of the volcanoes are covered with forest, and residential areas are in the lowlands along the boundary between the volcanic structures and swampy areas. The northern part of the study area is mainly lowland, and is composed of pyroclastic rocks and alluvium. In contrast, from the central area towards the southern part, there are steep slopes, mainly comprised of volcanic deposits from Mt. Karang and Mt. Parakasak eruptions. The northern parts of both volcanoes are very important because they are a source of groundwater and surface water, not only for local domestic users, but also to support industries in the nearby city of Cilegon. Cilegon, in the northern part of the study area, has a population of 374,559 and has approximately 119 factories (Bappeda and BPS, 2011).

Studies of the hydrogeological characteristics of this region are important to help plan for the sustainable use of water resources. Many studies using hydrochemistry and stable isotopes in groundwater have characterised 
recharge processes in different hydrogeological environments and flow system (Irawan et al. 2009; Lubis et al.2008; Delinom, 2009). Stable isotopes have been widely used as tracers to identify areas where precipitation contributes to groundwater recharge (Lee et al. 1999; Scholl et al. 2002; D'Alessandro et al. 2004). Comparison of the stable isotope composition of precipitation and groundwater is an excellent way to evaluate recharge mechanisms (Clark and Fritz, 1997; Jones and Banner, 2003).

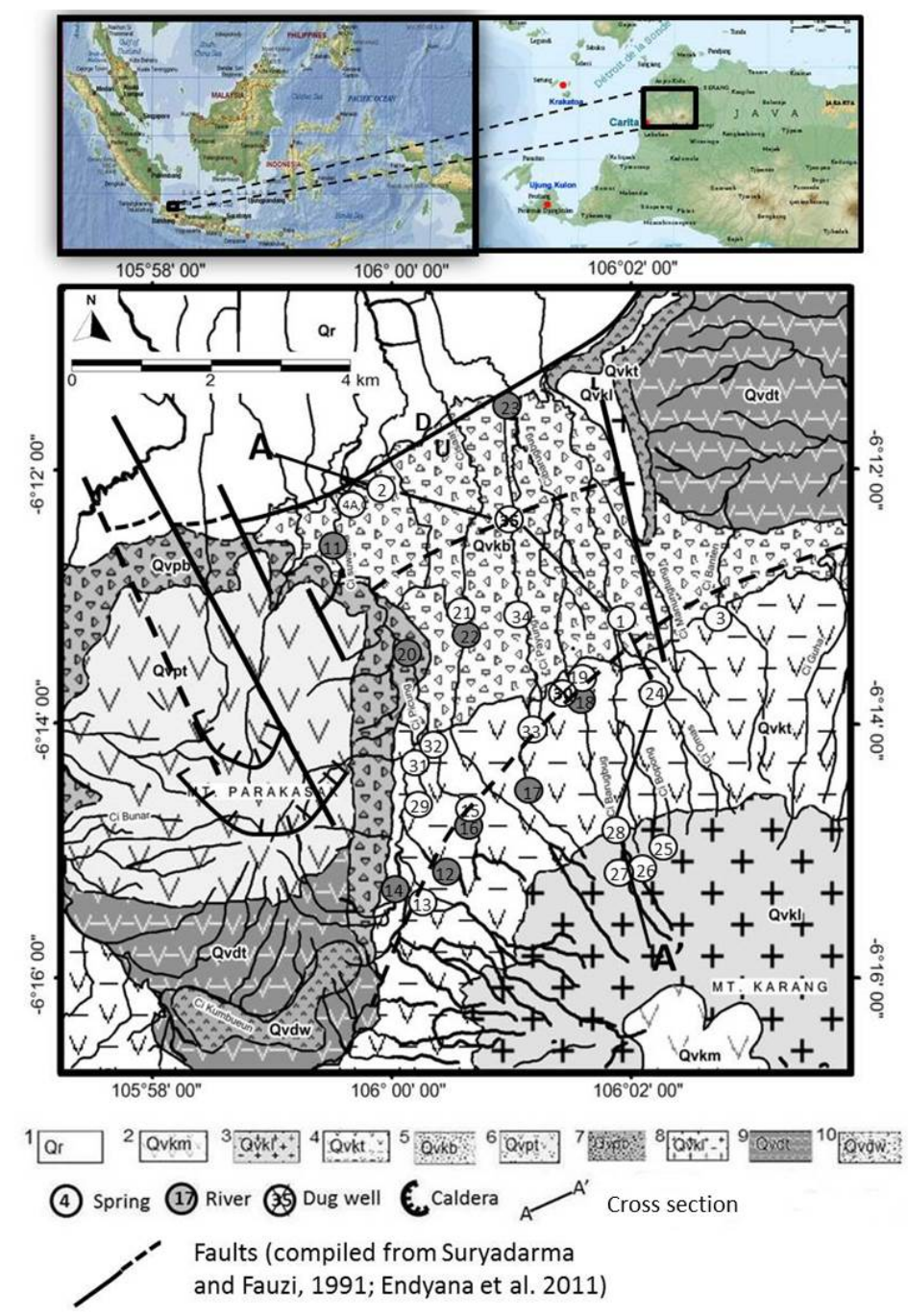

Figure 1. Map of (A) study area and (B) geological map of Mt. Karang area showing the lithological unit (1 sediment in Rawa Danau; 2 pyroxene andesite-basalt Mt. Karang; 3 andesitic-basaltic lava Mt. Karang; 4 tuff Mt.

Karang; 5 volcanic breccia Mt. Karang; 6 lapili tuff Mt. Parakasak; 7 volcanic breccia Mt. Parakasak; 8 andesitic-basaltic lava Mt. Kemuning; 9 old volcanic tuff (tufa Banten); 10 weathered tuff, part of the ancient volcanic lake product) and modified from Rusmana and Santosa (1991)

This study aims (1) to distinguish hydro-chemical and stable isotope characteristics of groundwater in the rainy and dry seasons and (2) to identify groundwater flow systems and recharge mechanism processes using hydro-chemical and stable isotope data. This is the first time that hydro-chemical and stable isotope properties of water have been studied in this area. The present study also aims to identify possible subsurface water-rock interactions in volcanic aquifer systems using hydro-chemical and stable isotope characteristics. The results of this study will be useful to develop a management plan for groundwater use in this area.

\section{Geological and Hydrogeological Settings}

The study area comprises two volcanoes and a wide swampy area that is filled with volcanic debris such as tuff and clay deposits. According to Van Bemmelen (1949), Rusmana et al. (1991) and Santosa (1991), volcanic activity in the study area took place from the Late Pleistocene until the Holocene, and resulted in the formation 
of the oldest volcanoes in the area, such as Mt. Karang and Mt. Parakasak. The eruptive centres lie on the southern side of the Danau Swamp depression. These peaks are volcanic feeders on the southern and southeastern slopes of Mt. Danau. Mt. Karang and Mt. Pulosari still have well-preserved volcanic cones and strato forms.

At its highest point, Mt. Karang is 1778 meters above sea level (a.s.l.). The mountain has evolved into a cone shape with clearly defined break-in slopes. River courses follow the shape of the mountain; they have steep gradients and narrow valleys on the upper slopes, and have radial drainage patterns. Mt. Karang is on the southern part of the main caldera, of which only the northern and eastern sides can be observed. The central part of the caldera is mostly covered by swamps and forests.

The geomorphology of the inner caldera is an indication of the most recent sedimentation; nearly all the sediment has come from the southern volcanic slopes and has been deposited in alluvial fans and fluvial systems in the caldera.

The oldest rocks in the study area are comprised of andesitic to basaltic lava products from the Mt. Kamuning unit, old volcanic tuff (Banten tuff), volcanic breccia from the Mt. Parakasak unit, lapili tuff from the Mt. Parakasak unit, volcanic breccia from the Mt. Karang unit, tuff from the Mt. Karang unit, andesitic to basaltic lava from the Mt. Karang unit, pyroxene andesite-basalt of the Mt. Karang unit and Rawa Danau sediment (Figure 1b).

A normal fault with a southwest-northeast strike direction controls where springs occur in the study area.

Based on the topography and rock associations, a volcanic composite cone can be divided into a central facies, proximal facies, medial facies and distal facies (Bronto, 2006). These different facies are found on the volcanoes, and can be identified in descending order from the central eruption point at the summit (central facies), to the upper slopes, lower slopes and foot plains in the surrounding area.

Sudibyo et al. (1995) and Suryaman (1999) divided the study area into three different aquifer systems, based on discharge mechanisms and aquifer capacity. (1) There is no aquifer associated with the peaks of both volcanoes (Mt. Karang and Mt. Parakasak), and so there is no groundwater worth mentioning. (2) The volcano slopes include an aquifer where groundwater flows through porous media and locally fractured media. Here, young volcanic deposits consist of multiple layers of laharic and pumiceous tuff that are between 3 and $12 \mathrm{~m}$ thick; they have well yields that are less than $5 \mathrm{~L} / \mathrm{s}$ and transmissivity values of about $600 \mathrm{~m}^{2} /$ day. (3) At the foot of the volcanoes there are aquifers where groundwater flows through porous media aquifers and locally fractured multiple layer lavas. The aquifer is between 5 and $25 \mathrm{~m}$ thick, and the well yield ranges between 5 and $25 \mathrm{~L} / \mathrm{s}$. (Sudibyo et al, 1995 and Suryaman, 1999).

\section{Climate}

In general, West Java has a humid-tropical climate, which is characterised by a dry season that lasts from June to September and a rainy season that lasts from November to March. There is a normally a transitional climatic season between April and October (Figure 2). The average annual rainfall of the study area from 1996 to 2011 was 2,143 $\mathrm{mm}$. According to Syariman and Hendarmawan (2010), the average evapotranspiration from the Cisuwarna River (in the study area) is $48 \%$. The annual rainfall at Ciomas, in the northern part of Mt. Karang, has a range of 1183-3213 $\mathrm{mm}$.

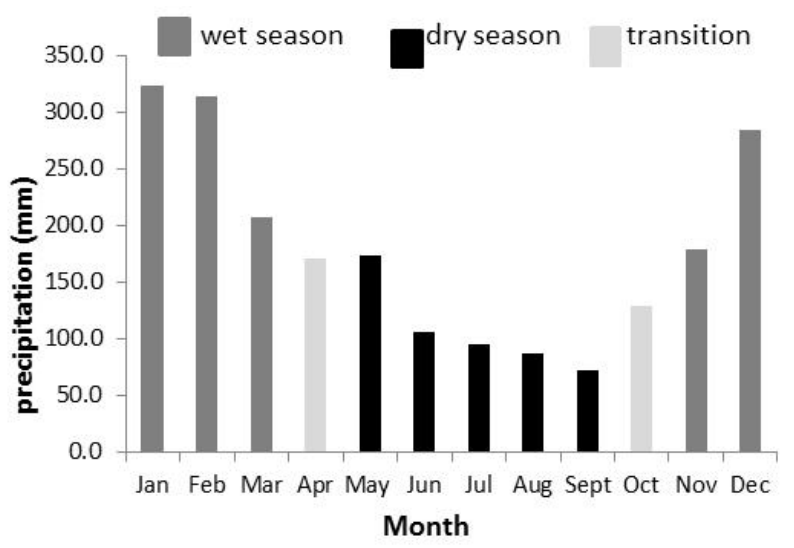

Figure 2. Averages monthly rainfall from 1996 to 2011 at Ciomas (personal communication, 2012). 


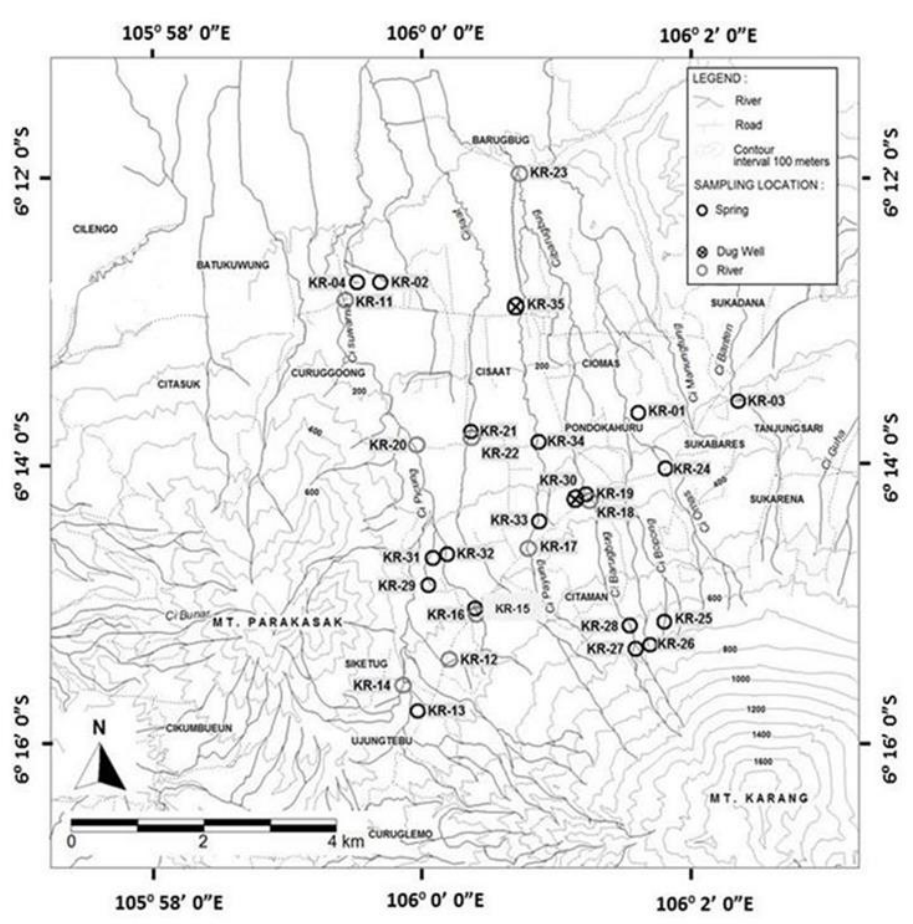

Figure 3. Map of sampling locations

\section{Methods}

\subsection{Sampling Locations}

Thirty rainy season water samples and twenty-seven dry season water samples were collected from springs (37 samples), dug wells (4 samples) and rivers (16 samples) in the northern parts of Mt. Karang and Mt. Parakasak, at elevations in the range of 96-673 $\mathrm{m}$ a.s.l., as shown in Figure 3.

There was no water discharge at three of the sampling locations, KR-15, KR-16 and KR-17, in the dry season. Springs are generally found in the area between the plain and the valley at elevations range of $120-425 \mathrm{~m}$ a.s.l. Samples KR-25, KR-26, KR-27 and KR-28 were collected from the slope of Mt. Karang at elevations of 620, 673, 646 and $588 \mathrm{~m}$ a.s.l., respectively. The two dug wells (KR-35 and KR-30) were located at elevations of 163 and $356 \mathrm{~m}$ a.s.l., in which the water levels were 3 and $5 \mathrm{~m}$ from the surface, respectively. Samples of river water were collected from the Cipayung and Cibarugbug Rivers in the Mt. Karang catchment area (KR-17, KR-18 and KR-23), at elevations in the range of 110-369 m a.s.l, and from the Cisuwarna River (KR-11, KR-12, KR-14 and KR-19), at elevations in the range of $120-431 \mathrm{~m}$ a.s.1.

\subsection{Sampling and Analytical Methods}

Field surveys were carried out in 2012, in February-March and July-August. Water samples were filtrated in situ with a $0.45-\mu \mathrm{m}$ membrane filter and stored in polyethylene bottles. Samples for $\mathrm{SiO} 2$ and cation analyses were acidified by adding $1 \mathrm{~mL}$ of $1 \mathrm{~N} \mathrm{HCl}$. $\mathrm{pH}$, temperature and electric conductivity (EC) were measured in the field. Samples were analysed for cations $\left(\mathrm{Li}^{+}, \mathrm{NH} 4^{+}, \mathrm{Na}^{+}, \mathrm{K}^{+}, \mathrm{Mg}^{2+}\right.$ and $\left.\mathrm{Ca}^{2+}\right)$ and anions $\left(\mathrm{Cl}^{-}, \mathrm{SO}_{2}^{-}\right.$and $\left.\mathrm{NO}^{-}\right)$ using ion chromatography (Dionex ICS-90). Samples were analysed for HCO3 by the titration method with 0.1 $\mathrm{M} \mathrm{HCl} \mathrm{immediately} \mathrm{after} \mathrm{sampling,} \mathrm{and} \mathrm{aluminium} \mathrm{(Al)} \mathrm{was} \mathrm{determined} \mathrm{by} \mathrm{ICP-AES} \mathrm{(Vista-MPX).} \mathrm{SiO2} \mathrm{was}$ determined by spectrophotometer using the molybdate yellow method (Hitachi U-1100). Isotopes in water samples were determined using the $\mathrm{CO} 2-\mathrm{H} 2$ equilibration method (Epstein \& Mayeda, 1953). Isotope ratios were measured by mass-spectrometer (DELTA Plus). Internal standards were calibrated using international reference materials V-SMOW and SLAP with analytical precisions of $\pm 0.1 \%$ for $\delta 18 \mathrm{O}$ and $\pm 1 \%$ for $\delta \mathrm{D}$.

\section{Results and Discussion}

\subsection{Water Chemistry}

Results of chemical analysis for the rainy and dry seasons are presented in Tables 1 and 2. pH values for spring, dug well and river water samples were generally weakly acidic to neutral. Values were in the range of 5.8-7.5 in 
the rainy season and 6.3-7.6 in the dry season, which indicates that the $\mathrm{pH}$ varied between the rainy and dry seasons. In the Figure 4a shows pH values for most samples (spring and dug well) decreased in the rainy season; this may be because of the $\mathrm{CO}_{2}$ gas solution in the soil water is lower in the rainy season than in the dry season. $\mathrm{HCO}_{3}{ }^{-}$values were also lower in the rainy season. Water temperatures in the rainy season were in the range of 22.2-26.9 ${ }^{\circ} \mathrm{C}$ in springs, $23.6-27.9{ }^{\circ} \mathrm{C}$ in the dug wells and $22-24.4{ }^{\circ} \mathrm{C}$ in the river water. In the dry season, water temperatures were in the range of $22.3-27.1^{\circ} \mathrm{C}$ in springs, $23.3-29.6{ }^{\circ} \mathrm{C}$ in the dug wells and $23.7-26.8{ }^{\circ} \mathrm{C}$ in river water. Temperature values in the spring, dug well and river samples increased at some sites in the dry season (Figure 4b). In particular, increases of temperature were observed in spring (KR-21, KR-3 and KR-25), dug well (KR-30 and KR-35) and river (KR-11) samples collected in the central part of Mt. Karang. The increase in temperature might be due to groundwater and surface water mixing.

Table 1. Field measurements and chemical analysis for the rainy season

\begin{tabular}{|c|c|c|c|c|c|c|c|c|c|c|c|c|c|c|c|c|c|c|c|}
\hline Sample ID & Obs. & $\begin{array}{c}\text { Elev. } \\
\text { (m a.s.l) }\end{array}$ & Date & $\begin{array}{l}\text { Temp. } \\
\left({ }^{\circ} \mathrm{C}\right)\end{array}$ & $\mathrm{pH}$ & $\begin{array}{c}\mathrm{Ec} \\
\mathrm{mS} / \mathbf{m}\end{array}$ & $\mathbf{L i}^{+}$ & $\mathrm{Na}^{+}$ & $\mathbf{K}^{+}$ & $\mathbf{M g}^{2+}$ & $\mathrm{Ca}^{2+}$ & $\begin{array}{l}\mathrm{Cl} \\
{ }_{\mathrm{mg}}\end{array}$ & $\mathrm{NO}_{3}^{-}$ & $504^{2-}$ & $\mathrm{HCO}_{3}^{-}$ & $\mathrm{SiO}_{2}$ & Al & $\begin{array}{l}\delta \mathbf{D} \\
\%\end{array}$ & $\begin{array}{c}\delta^{18} \mathbf{O} \\
\%\end{array}$ \\
\hline KR-1 & $\mathrm{s}$ & 263 & 120229 & 24.1 & 5.8 & 14.7 & ND & 9.34 & 3.36 & 4.13 & 10.7 & 2.21 & 2.73 & 4.44 & 71.0 & 75.5 & 0.05 & -42 & -7.0 \\
\hline KR-2 & $\mathrm{s}$ & 130 & 120229 & 25.4 & 5.8 & 15.2 & ND & 8.73 & 3.37 & 4.31 & 13.4 & 2.44 & 2.87 & 6.79 & 77.0 & 80.0 & 0.05 & -37 & -6.3 \\
\hline KR-3 & $\mathrm{s}$ & 300 & 120229 & 24.9 & 6.0 & 19.2 & ND & 11.9 & 3.68 & 6.20 & 14.3 & 2.62 & 2.84 & 3.63 & 107 & 77.8 & 0.05 & -42 & -7.0 \\
\hline KR-4A & $\mathrm{s}$ & 120 & 120301 & 26.9 & 6.0 & 11.9 & ND & 7.60 & 2.48 & 3.09 & 10.2 & 3.33 & 5.06 & 4.73 & 48.8 & 63.5 & 0.10 & -39 & -6.2 \\
\hline KR-4C & $\mathrm{s}$ & 120 & 120301 & 25.6 & 6.3 & 16.6 & ND & 8.50 & 3.23 & 4.16 & 13.1 & 2.56 & 3.18 & 7.02 & 64.7 & 78.9 & 0.05 & -38 & -6.3 \\
\hline KR-13 & $\mathrm{s}$ & 425 & 120302 & 24.8 & 6.0 & 11.2 & ND & 6.83 & 1.02 & 2.88 & 13.3 & 3.01 & 4.17 & 5.82 & 51.5 & 32.7 & 0.07 & -39 & -6.6 \\
\hline KR-15 & $\mathrm{s}$ & 398 & 120302 & 24.3 & 6.2 & 15.1 & ND & 7.55 & 2.56 & 3.59 & 13.6 & 3.54 & 3.57 & 11.6 & 61.0 & 57.8 & 0.06 & -40 & -6.6 \\
\hline KR-19 & $\mathrm{s}$ & 350 & 120303 & 23.3 & 6.6 & 13.9 & ND & 8.19 & 3.52 & 3.52 & 11.7 & 1.76 & 2.77 & 3.14 & 70.2 & 77.2 & 0.06 & -41 & -6.9 \\
\hline KR-21 & $\mathrm{s}$ & 234 & 120303 & 23.5 & 6.4 & 13.1 & ND & 7.75 & 2.52 & 3.06 & 10.2 & 4.80 & 4.28 & 6.27 & 54.2 & 54.4 & 0.23 & -36 & -5.6 \\
\hline KR-24 & $\mathrm{s}$ & 331 & 120305 & 25.1 & 6.6 & 12.3 & ND & 8.92 & 3.23 & 3.06 & 8.50 & 2.63 & 3.74 & 1.21 & 61.0 & 86.3 & 0.09 & -41 & -6.6 \\
\hline KR-25 & $\mathrm{S}$ & 620 & 120305 & 22.3 & 7.4 & 8.6 & ND & 4.33 & 3.14 & 2.05 & 6.92 & 1.30 & 5.33 & 2.65 & 39.7 & 35.0 & 0.08 & -43 & -7.1 \\
\hline KR-26 & $\mathrm{s}$ & 673 & 120305 & 22.7 & 6.8 & 11.9 & ND & 7.92 & 2.50 & 2.27 & 10.0 & 1.43 & 3.17 & 0.50 & 64.1 & 71.5 & 0.07 & -38 & -6.6 \\
\hline KR-27 & $\mathrm{s}$ & 646 & 120305 & 22.2 & 7.2 & 8.5 & ND & 5.46 & 2.51 & 1.83 & 6.82 & 1.30 & 1.63 & 1.52 & 42.7 & 43.5 & 0.07 & -43 & -7.1 \\
\hline KR-28 & $\mathrm{s}$ & 588 & 120305 & 22.7 & 7.5 & 7.7 & ND & 4.78 & 2.64 & 1.68 & 5.85 & 1.44 & 3.16 & 1.71 & 33.5 & 38.5 & 0.06 & -42 & -7.1 \\
\hline KR-29 & $\mathrm{s}$ & 353 & 120305 & 25.2 & 6.6 & 15.0 & ND & 8.17 & 2.42 & 4.48 & 13.4 & 2.52 & 3.26 & 5.08 & 79.3 & 62.1 & 0.06 & -36 & -6.1 \\
\hline KR-31 & $\mathrm{s}$ & 334 & 120306 & 24.9 & 6.6 & 15.3 & ND & 7.83 & 2.60 & 4.17 & 13.6 & 2.84 & 3.34 & 7.08 & 73.2 & 58.0 & 0.06 & -38 & -6.3 \\
\hline KR-32 & $\mathrm{s}$ & 335 & 120306 & 24.9 & 6.3 & 5.6 & ND & 7.34 & 2.16 & 3.44 & 11.3 & 3.60 & 4.75 & 10.3 & 45.8 & 44.6 & 0.06 & -39 & -6.5 \\
\hline KR-33 & $\mathrm{s}$ & 334 & 120307 & 25.1 & 6.3 & 13.2 & ND & 6.98 & 1.76 & 3.96 & 10.7 & 4.38 & 8.78 & 1.94 & 56.9 & 46.7 & 0.05 & -40 & -6.5 \\
\hline KR-34 & $\mathrm{s}$ & 250 & 120307 & 25.2 & 6.5 & 16.1 & ND & 8.83 & 3.44 & 4.66 & 13.5 & 3.06 & 3.76 & 4.78 & 85.4 & 66.7 & 0.08 & -40 & -6.5 \\
\hline KR-30 & DW & 356 & 120305 & 22.0 & 6.5 & 17.3 & ND & 9.44 & 4.13 & 4.42 & 14.3 & 3.76 & 10.1 & 3.31 & 78.1 & 69.3 & 0.06 & -40 & -6.6 \\
\hline KR-35 & DW & 163 & 120307 & 24.4 & 6.3 & 10.9 & ND & 7.15 & 3.62 & 2.13 & 6.61 & 5.31 & 8.70 & 5.48 & 33.6 & 40.5 & 0.49 & -37 & -5.9 \\
\hline KR-11 & $\mathrm{R}$ & 120 & 120302 & 25.8 & 7.3 & 6.7 & ND & 4.22 & 1.45 & 1.72 & 4.98 & 1.99 & 2.06 & 5.57 & 27.0 & 24.1 & 0.20 & -48 & -7.5 \\
\hline KR-12 & $\mathrm{R}$ & 431 & 120302 & 25.0 & 6.9 & 7.2 & ND & 4.35 & 2.01 & 1.52 & 5.10 & 2.21 & 2.30 & 7.37 & 24.4 & 24.1 & 0.80 & -44 & -7.0 \\
\hline KR-14 & $\mathrm{R}$ & 410 & 120302 & 27.4 & 7.2 & 5.4 & ND & 3.66 & 1.43 & 1.56 & 3.55 & 1.94 & 2.23 & 1.98 & 21.4 & 21.8 & 0.32 & -43 & -6.9 \\
\hline KR-16 & $\mathrm{R}$ & 397 & 120302 & 25.0 & 6.7 & 14.9 & ND & 6.02 & 5.31 & 2.69 & 16.1 & 2.94 & 3.68 & 18.1 & 56.4 & 36.7 & 0.08 & -48 & -7.5 \\
\hline KR-17 & $\mathrm{R}$ & 369 & 120302 & 25.1 & 6.8 & 11.9 & ND & 6.63 & 2.81 & 3.37 & 9.93 & 2.48 & 1.92 & 1.49 & 64.7 & 46.9 & 0.13 & -40 & -6.6 \\
\hline KR-18 & $\mathrm{R}$ & 349 & 120303 & 23.6 & 6.6 & 4.4 & ND & 8.53 & 3.75 & 3.63 & 12.5 & 2.29 & 3.06 & 3.38 & 79.5 & 74.9 & 0.07 & -42 & -6.9 \\
\hline KR-20 & $\mathrm{R}$ & 238 & 120303 & 27.9 & 7.3 & 8.4 & ND & 5.05 & 1.57 & 2.23 & 6.0 & 2.36 & 2.39 & 7.21 & 30.5 & 28.7 & 0.55 & -41 & -6.6 \\
\hline KR-22 & $\mathrm{R}$ & 234 & 120303 & 27.0 & 6.9 & 10.3 & ND & 6.75 & 2.18 & 2.58 & 7.74 & 3.64 & 6.07 & 5.92 & 39.6 & 37.2 & 0.45 & -39 & -5.9 \\
\hline KR-23 & $\mathrm{R}$ & 110 & 120304 & 27.3 & 7.2 & 15.7 & ND & 11.3 & 4.31 & 4.12 & 11.2 & 5.08 & 4.53 & 6.14 & 73.2 & 45.2 & 0.87 & -38 & -5.7 \\
\hline
\end{tabular}

Table 2. Field measurements and chemical analysis for the dry season

\begin{tabular}{|c|c|c|c|c|c|c|c|c|c|c|c|c|c|c|c|c|c|c|c|}
\hline Sample ID & Obs. & $\begin{array}{c}\text { Elev. } \\
\text { (m asl) }\end{array}$ & Date & $\begin{array}{c}\text { Temp. } \\
\left({ }^{\circ} \mathrm{C}\right)\end{array}$ & $\mathrm{pH}$ & $\begin{array}{c}\mathbf{E c} \\
\mathrm{mS} / \mathrm{m}\end{array}$ & $\mathbf{L i}^{+}$ & $\mathrm{Na}^{+}$ & $\mathbf{K}^{+}$ & $\mathrm{Mg}^{2+}$ & $\mathrm{Ca}^{2+}$ & $\begin{array}{r}\mathrm{Cr} \\
\mathrm{mg} / \mathrm{L} \\
\end{array}$ & $\mathrm{NO}_{3}^{-}$ & $\mathrm{SO}^{2-}$ & $\mathrm{HCO}_{3}^{-}$ & $\mathrm{SiO}_{2}$ & Al & $\begin{array}{l}\delta \mathbf{D} \\
\%\end{array}$ & $\begin{array}{c}\delta^{18} \mathbf{O} \\
\%\end{array}$ \\
\hline KR-1 & $\mathrm{s}$ & 263 & 120729 & 23.8 & 6.9 & 9.2 & ND & 9.65 & 3.43 & 4.12 & 10.5 & 2.28 & 2.49 & 4.49 & 78.1 & 78.9 & 0.02 & -42 & -7.1 \\
\hline KR-2 & $\mathrm{s}$ & 130 & 120729 & 25.5 & 6.8 & 19.0 & ND & 8.85 & 3.44 & 4.29 & 13.1 & 2.18 & 2.04 & 7.01 & 79.3 & 86.0 & 0.03 & -38 & -6.4 \\
\hline KR-3 & $\mathrm{s}$ & 300 & 120801 & 26.6 & 6.8 & 17.7 & ND & 12.6 & 3.79 & 6.35 & 14.1 & 2.48 & 2.07 & 4.10 & 102 & 81.6 & 0.02 & -43 & -7.1 \\
\hline KR-4A & S & 120 & 120729 & 26.3 & 6.4 & 23.6 & ND & 8.78 & 3.00 & 3.86 & 12.2 & 2.59 & 2.78 & 6.20 & 73.2 & 77.2 & 0.01 & -38 & -6.1 \\
\hline KR-4C & $\mathrm{S}$ & 120 & 120729 & 26.5 & 6.5 & 16.1 & ND & 8.89 & 3.36 & 4.22 & 13.0 & 2.30 & 2.30 & 6.91 & 69.5 & 86.6 & 0.01 & -38 & -6.3 \\
\hline KR-13 & $\mathrm{s}$ & 425 & 120731 & 24.5 & 6.3 & 11.5 & ND & 7.07 & 1.01 & 3.08 & 9.31 & 3.16 & 4.39 & 6.25 & 50.0 & 41.0 & 0.05 & -38 & -6.5 \\
\hline KR-15* & $\mathrm{s}$ & 398 & 120731 & ND & ND & ND & ND & ND & $\mathrm{ND}$ & ND & ND & ND & ND & ND & ND & $\mathrm{ND}$ & ND & $\mathrm{ND}$ & ND \\
\hline KR-19 & $\mathrm{s}$ & 350 & 120731 & 23.3 & 6.5 & 7.20 & ND & 8.44 & 3.59 & 3.40 & 11.3 & 1.91 & 2.45 & 3.40 & 67.1 & 81.6 & 0.03 & -41 & -6.9 \\
\hline KR-21 & S & 234 & 120801 & 27.1 & 6.6 & 12.1 & ND & 7.84 & 2.55 & 3.19 & 10.5 & 3.05 & 2.13 & 6.02 & 63.4 & 65.2 & 0.02 & -33 & -5.5 \\
\hline KR-24 & $\mathrm{s}$ & 331 & 120731 & 25.3 & 6.5 & 13.4 & ND & 9.28 & 3.60 & 3.54 & 9.92 & 2.94 & 4.31 & 1.40 & 68.3 & 91.5 & 0.04 & -38 & -6.7 \\
\hline KR-25 & $\mathrm{S}$ & 620 & 120730 & 23.4 & 7.4 & 12.8 & ND & 9.24 & 3.27 & 3.64 & 11.4 & 1.44 & 2.87 & 1.25 & 79.3 & 80.5 & 0.04 & -38 & -6.4 \\
\hline KR-26 & $\mathrm{s}$ & 673 & 120730 & 23.4 & 7.1 & 12.5 & ND & 8.79 & 2.86 & 2.54 & 11.4 & 1.52 & 3.78 & 0.00 & 68.3 & 82.0 & 0.02 & -38 & -6.5 \\
\hline KR-27 & $\mathrm{s}$ & 646 & 120730 & 22.7 & 7.6 & 10.7 & ND & 8.05 & 1.96 & 2.24 & 9.18 & 1.48 & 1.43 & 0.57 & 61.0 & 73.8 & 0.04 & -38 & -6.6 \\
\hline KR-28 & $\mathrm{s}$ & 588 & 120730 & 22.3 & 7.6 & 11.8 & $\mathrm{ND}$ & 6.19 & 3.61 & 2.96 & 10.0 & 1.44 & 2.49 & 1.43 & 62.2 & 53.0 & 0.02 & -41 & -7.0 \\
\hline
\end{tabular}




\begin{tabular}{|c|c|c|c|c|c|c|c|c|c|c|c|c|c|c|c|c|c|c|c|}
\hline KR-29 & $\mathrm{S}$ & 353 & 120802 & 25.3 & 6.6 & 15.0 & $\mathrm{ND}$ & 8.68 & 2.54 & 4.81 & 13.3 & 2.61 & 3.2 & 5.52 & 86.6 & 77.1 & 0.03 & -36 & -6.2 \\
\hline KR-31 & $\mathrm{S}$ & 334 & 120802 & 24.8 & 6.6 & 14.2 & ND & 8.15 & 2.70 & 4.33 & 13.9 & 2.82 & 2.8 & 7.66 & 70.8 & 72.7 & 0.02 & -38 & -6.4 \\
\hline KR-32 & $\mathrm{s}$ & 335 & 120802 & 24.8 & 6.6 & 14.2 & $\mathrm{ND}$ & 7.83 & 2.23 & 3.73 & 12.7 & 3.07 & 2.85 & 11.3 & 61.0 & 62.3 & 0.04 & -39 & -6.5 \\
\hline KR-33 & $\mathrm{s}$ & 334 & 120802 & 25.3 & 6.8 & 14.8 & $\mathrm{ND}$ & 8.30 & 2.19 & 4.74 & 13.1 & 3.86 & 7.7 & 2.02 & 73.2 & 73.3 & 0.04 & -39 & -6.4 \\
\hline KR-34 & $\mathrm{s}$ & 250 & 120801 & 25.1 & 6.8 & 16.9 & $\mathrm{ND}$ & 9.38 & 3.64 & 4.91 & 14.0 & 3.84 & 6.38 & 5.32 & 79.3 & 81.5 & 0.04 & -40 & -6.6 \\
\hline KR-30 & DW & 356 & 120731 & 23.7 & 6.4 & 14.4 & $\mathrm{ND}$ & 8.98 & 3.87 & 3.84 & 12.5 & 2.20 & 4.52 & 2.82 & 78.1 & 83.7 & 0.06 & -39 & -6.6 \\
\hline KR-35 & DW & 163 & 120803 & 25.9 & 6.6 & 11.6 & $\mathrm{ND}$ & 7.20 & 3.50 & 1.82 & 9.26 & 4.51 & 6.4 & 4.96 & 42.7 & 49.8 & 0.04 & -35 & -5.6 \\
\hline KR-11 & $\mathrm{R}$ & 120 & 120801 & 29.5 & 7.6 & 15.5 & $\mathrm{ND}$ & 9.98 & 2.73 & 5.21 & 11.6 & 2.71 & 1.32 & 9.56 & 72.0 & 56.4 & 0.03 & -35 & -5.8 \\
\hline KR-12 & $\mathrm{R}$ & 431 & 120731 & 23.3 & 6.9 & 7.9 & $\mathrm{ND}$ & 5.65 & 1.64 & 1.96 & 6.41 & 2.59 & 2.11 & 7.18 & 32.9 & 31.6 & 0.03 & -35 & -5.8 \\
\hline KR-14 & $\mathrm{R}$ & 410 & 120802 & 25.5 & 7.1 & 7.5 & $\mathrm{ND}$ & 5.70 & 1.84 & 2.28 & 4.91 & 1.36 & 0.50 & 1.34 & 41.5 & 48.7 & 0.03 & -34 & -6.0 \\
\hline KR-16* & $\mathrm{R}$ & 397 & 120731 & $\mathrm{ND}$ & $\mathrm{ND}$ & $\mathrm{ND}$ & $\mathrm{ND}$ & ND & ND & ND & ND & ND & $\mathrm{ND}$ & $\mathrm{ND}$ & ND & ND & $\mathrm{ND}$ & $\mathrm{ND}$ & $\mathrm{ND}$ \\
\hline KR-17* & $\mathrm{R}$ & 369 & 120731 & $\mathrm{ND}$ & ND & ND & $\mathrm{ND}$ & ND & ND & ND & ND & ND & $\mathrm{ND}$ & $\mathrm{ND}$ & ND & ND & $\mathrm{ND}$ & $\mathrm{ND}$ & $\mathrm{ND}$ \\
\hline KR-18 & $\mathrm{R}$ & 349 & 120731 & 23.6 & 6.6 & 13.9 & $\mathrm{ND}$ & 9.06 & 4.87 & 3.77 & 12.7 & 2.56 & 4.81 & 3.43 & 79.3 & 80.0 & 0.02 & -39 & -6.9 \\
\hline KR-20 & $\mathrm{R}$ & 238 & 120801 & 26.7 & 7.2 & 11.2 & $\mathrm{ND}$ & 7.08 & 2.22 & 3.25 & 8.25 & 4.04 & 1.30 & 10.7 & 43.9 & 28.9 & 0.05 & -30 & -5.0 \\
\hline KR-22 & $\mathrm{R}$ & 234 & 120801 & 25.6 & 6.6 & 16.6 & $\mathrm{ND}$ & 10.6 & 4.64 & 4.36 & 15.0 & 6.15 & 10.6 & 6.63 & 85.4 & 64.1 & 0.02 & -33 & -5.5 \\
\hline KR-23 & $\mathrm{R}$ & 110 & 120803 & 25.5 & 6.8 & 18.1 & $\mathrm{ND}$ & 12.4 & 4.39 & 5.04 & 12.8 & 5.03 & 2.41 & 9.54 & 78.1 & 61.9 & 0.05 & -26 & -4.5 \\
\hline
\end{tabular}

$\mathrm{ND}=$ not detected; $*=$ no discharge; $\mathrm{T}=$ temperature; $\mathrm{S}=$ spring; $\mathrm{R}=$ river; $\mathrm{DW}=$ dug well.

Figure $4 \mathrm{c}$ shows the electrical conductivity (EC) values for spring, river and dug well samples were in the range of 4.4-19.2 $\mathrm{mS} / \mathrm{m}$ in the rainy season. These values were higher than those in the dry season, during which they had a range of $7.20-23.6 \mathrm{mS} / \mathrm{m}$. Increased dry season EC values, relative to those in the rainy season, were observed in samples KR-2, 4A, 25, 28 and KR-32 (spring water) and in all the river water samples, which indicates mixing of spring and river waters with water from the shallow aquifer. In fact, EC values in the river water increased in the dry season, implying that rainwater was the main water supply. Moreover, the EC values for two spring samples (KR-1 and KR-19) and one dug well sample (KR-30) in the unconfined aquifer were low in the dry season but increased in the rainy season. The higher EC values may be due to water percolating through loose sediments, resulting in increased mineral dissolution in aquifers. The sampling location also supports this theory, as it was situated along the fault zones where soil erosion could have occurred.
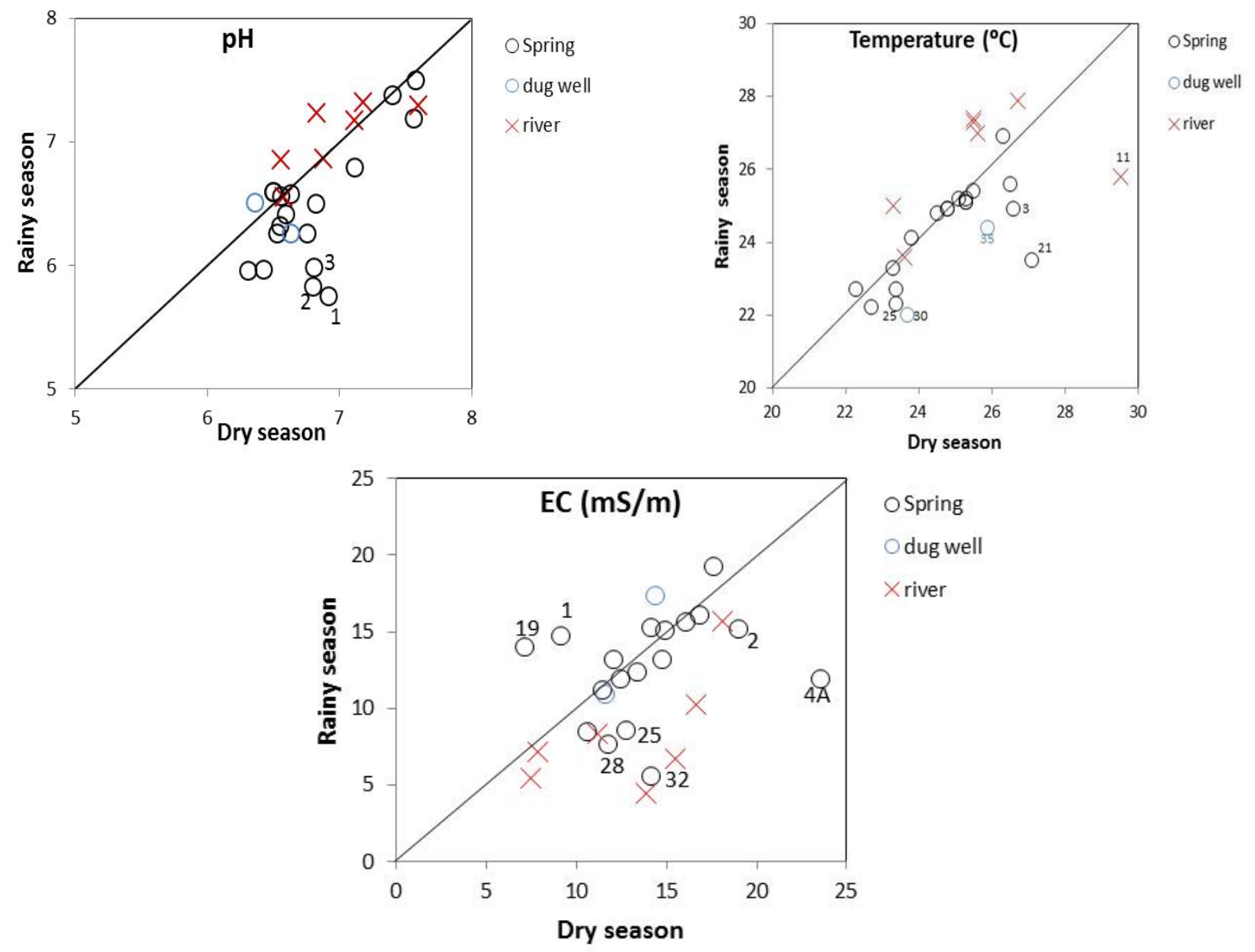

Figure 4. Plots of temperature, $\mathrm{pH}$ and EC from spring, dug well and river water samples in rainy and dry seasons 
Concentrations of major chemical elements for spring and dug well samples in the different seasons are compared in Figure 5. In the rainy season the average concentrations of $\mathrm{Na}^{+}, \mathrm{K}^{+}, \mathrm{Mg}^{2+}, \mathrm{Ca}^{2+}, \mathrm{Cl}^{-}, \mathrm{SO}_{4}{ }^{2-}$ and $\mathrm{HCO}_{3}{ }^{-}$were $7.8 \mathrm{mg} / \mathrm{L}, 2.9 \mathrm{mg} / \mathrm{L}, 3.5 \mathrm{mg} / \mathrm{L}, 11 \mathrm{mg} / \mathrm{L}, 2.8 \mathrm{mg} / \mathrm{L}, 4.4 \mathrm{mg} / \mathrm{L}$ and $61.9 \mathrm{mg} / \mathrm{L}$, respectively. In the dry season, the average concentrations of $\mathrm{Na}^{+}, \mathrm{K}^{+}, \mathrm{Mg}^{2+}, \mathrm{Ca}^{2+}, \mathrm{Cl}^{-}, \mathrm{SO}_{4}{ }^{2-}$ and $\mathrm{HCO}_{3}{ }^{-}$were $8.6 \mathrm{mg} / \mathrm{L}, 3 \mathrm{mg} / \mathrm{L}$, $3.8 \mathrm{mg} / \mathrm{L}, 11.7 \mathrm{mg} / \mathrm{L}, 2.6 \mathrm{mg} / \mathrm{L}, 4.4 \mathrm{mg} / \mathrm{L}$ and $70.7 \mathrm{mg} / \mathrm{L}$, respectively.
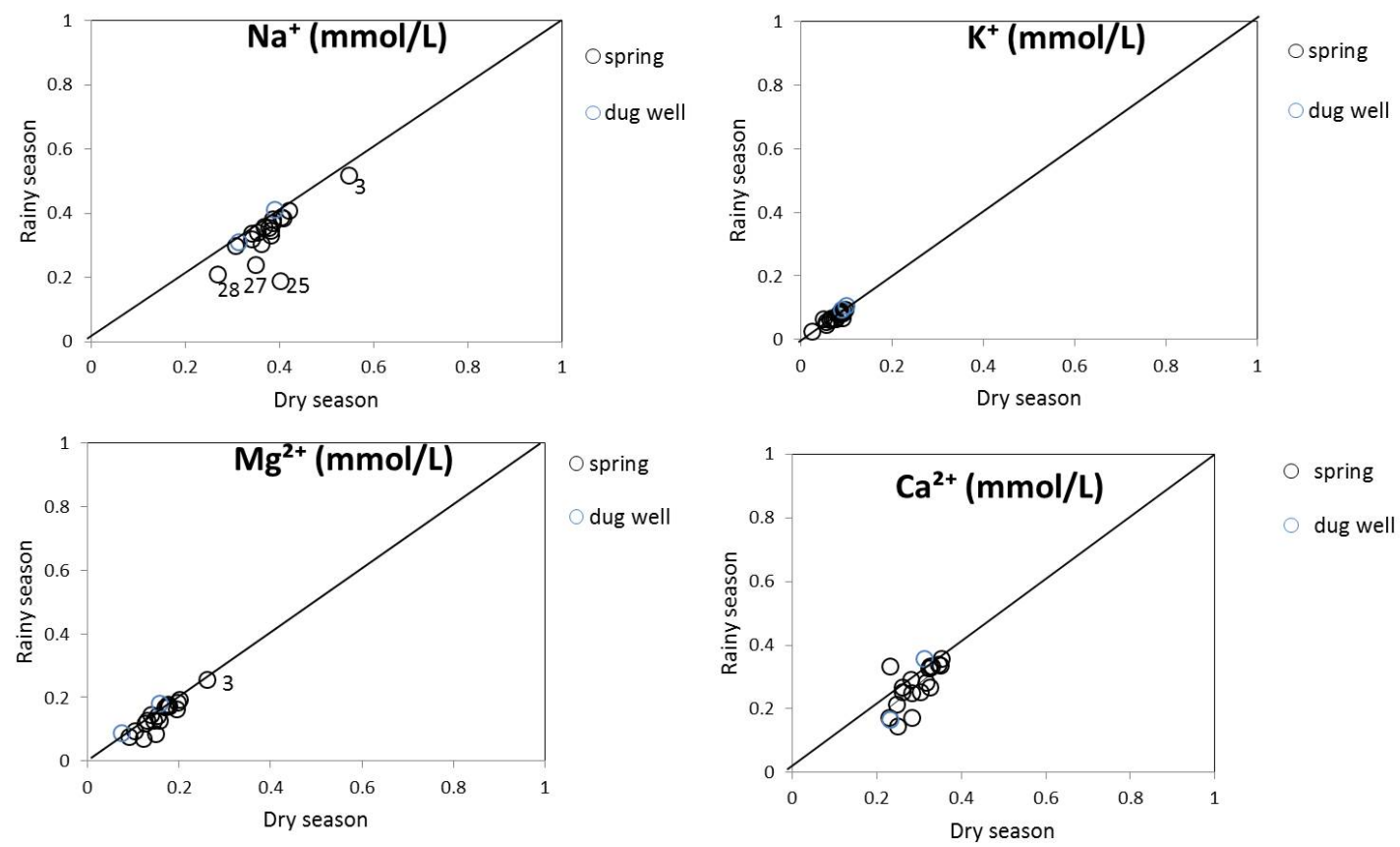

\section{spring \\ dug well} ospring dug well
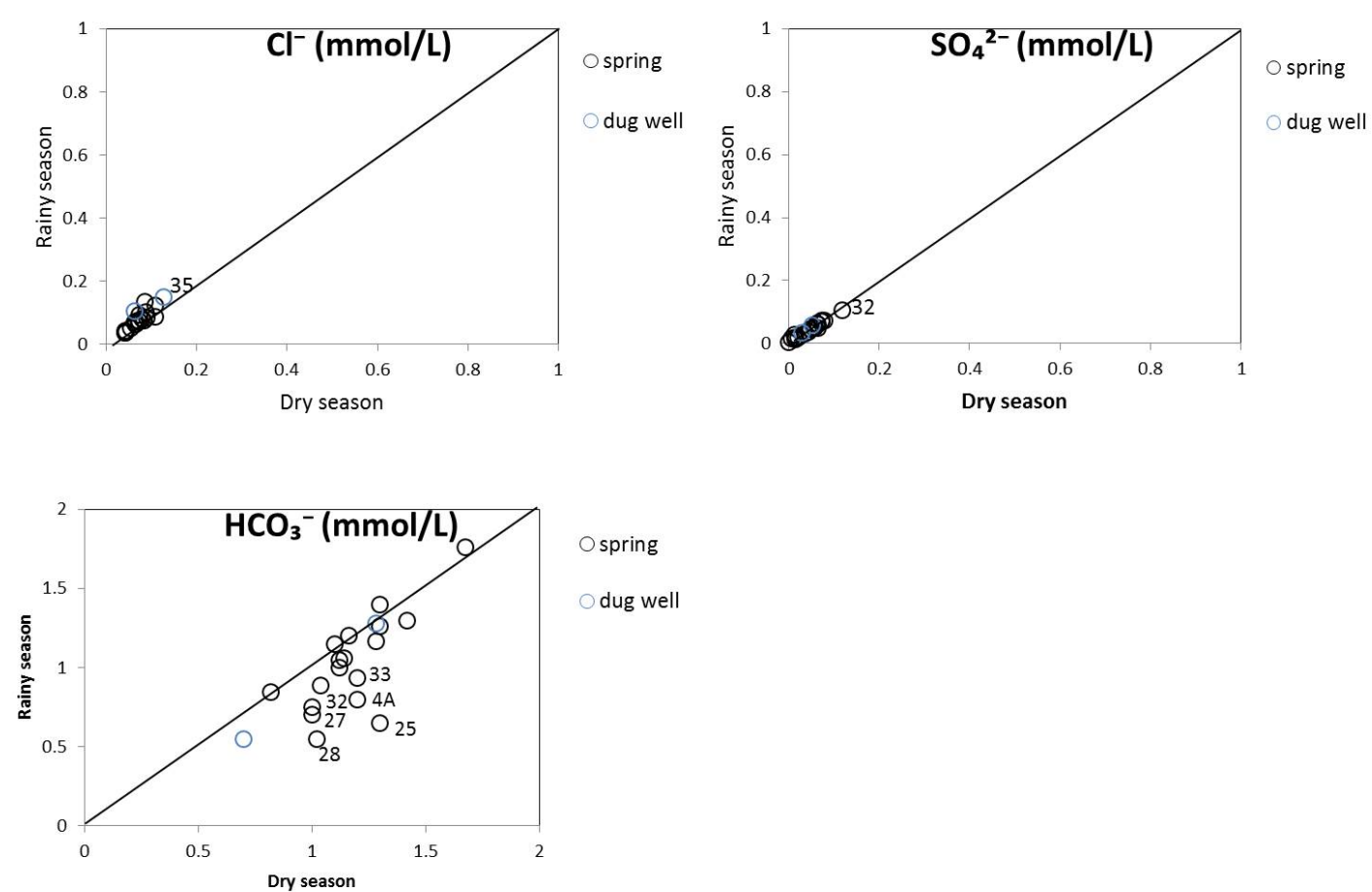

dug well

Figure 5. Comparison of major ions in rainy and dry seasons for spring and dug well samples in the same sampling locations

Data plotted on the solid line indicates that the concentrations in the two seasons were the same; data plotted below the line indicates higher values in the dry season and vice versa. 
Many data points for $\mathrm{Ca}^{2+}$ and $\mathrm{HCO}_{3}{ }^{-}$deviated from the line, which may indicate that $\mathrm{Ca}^{2+}$ and $\mathrm{HCO}_{3}{ }^{-}$are sensitive to the seasons. The higher $\mathrm{Ca}^{2+}$ concentrations in the dry season are due to intensive interactions between water and Ca-plagioclase. These interactions are infrequent in the rainy season because they are controlled by rainwater. Concentration of $\mathrm{HCO}_{3}{ }^{-}$was high in the dry season in samples from KR-25, 4A, 27, 28, 33 and 32. Additionally, $\mathrm{HCO}_{3}{ }^{-}$originates from either infiltration of rain water that has been equilibrated with $\mathrm{CO}_{2}$ in the atmosphere, or from $\mathrm{CO}_{2}$ that has been generated by respiration of organic material (Appelo \& Postma, 2005). This indicates that the water may have flowed through the shallow aquifer system or may have been mixed with the surface water. This is also supported by the variation in the $\mathrm{EC}$ values in samples from different seasons. However, the constant $\mathrm{Ca}^{2+}$ and $\mathrm{HCO}_{3}{ }^{-}$concentrations indicate that the water flowed in the deep aquifers.

The KR-13 sample, collected at an elevation of $425 \mathrm{~m}$ a.s.l., had a high $\mathrm{Ca}^{2+}$ concentration in the rainy season, which is due to the mixing of two groundwater flow systems. Alternatively, KR-13 may have originated from recharge of relatively localised precipitation falling on the shallow aquifers. Concentrations of the $\mathrm{Na}^{+}$ion were higher in the dry season than in the rainy season in samples KR-25, KR-27 and KR-28. These water samples were collected at elevations between 588 and $646 \mathrm{~m}$ a.s.l., where water flowed out from the lava formation. In the dry season, active fluid-rock interactions occur between water and minerals, facilitated by low water velocities in formations that contain plagioclase. Concentrations of $\mathrm{Na}^{+}$and $\mathrm{Mg}^{2+}$ were high in the KR-3 sample collected from a site at $300 \mathrm{~m}$ a.s.l. associated with the tuff aquifer. High $\mathrm{Na}^{+}$concentrations in samples may indicate that the samples originated from feldspar or anorthite weathering (Appelo \& Postma, 2005). Additionally, concentrations of $\mathrm{Na}^{+}$and $\mathrm{Mg}^{2+}$ in KR-3 did not show any seasonal variation, which implies that the water flows in the deep aquifer for a longer time period, and then discharges to the surface. The variation in the ionic content of water samples may be due to different mineral compounds in the aquifer where water-rock interactions occur. Therefore, different stratigraphic horizons, which are characterised by different rock types, may have contributed to the chemistry of percolating waters. However, concentrations of $\mathrm{K}^{+}$and $\mathrm{SO}_{4}{ }^{2-}$ may be relatively constant in some samples between the different seasons. Concentrations of $\mathrm{SO}_{4}{ }^{2-}$ were high in the KR-32 spring sample, which may have come from a formation in which there were anhydrite interactions or from oxidation of pyrite (Garrels, 1967). Additionally, concentration of $\mathrm{Cl}^{-}$was higher in one dug well sample (KR-35), in the rainy and dry season. These elevated concentrations may be the result of fertiliser pollution or human activities, because the samples were collected close to populated areas.

Water types and sources were determined using piper and stiff diagrams. Results from chemical analysis were plotted on a piper diagram, as shown in Figure 6A and 6B. All samples fall in the same $\mathrm{Ca}-\mathrm{Na}$ and $\mathrm{HCO}_{3}$ corner regardless of the season, which indicates that the chemical characteristics of groundwater generally remain unchanged. The stiff diagrams for spring, dug well and river water samples in the rainy and dry seasons are shown in Figure 7A and 7B. All water samples for both seasons were classified as the Ca-Na- $\mathrm{HCO}_{3}$ type. The fact that the dominant cation was $\mathrm{Ca}^{2+}$ indicates that this water may have flowed through a rock formation composed of andesitic-basaltic rocks with Ca-plagioclase minerals.
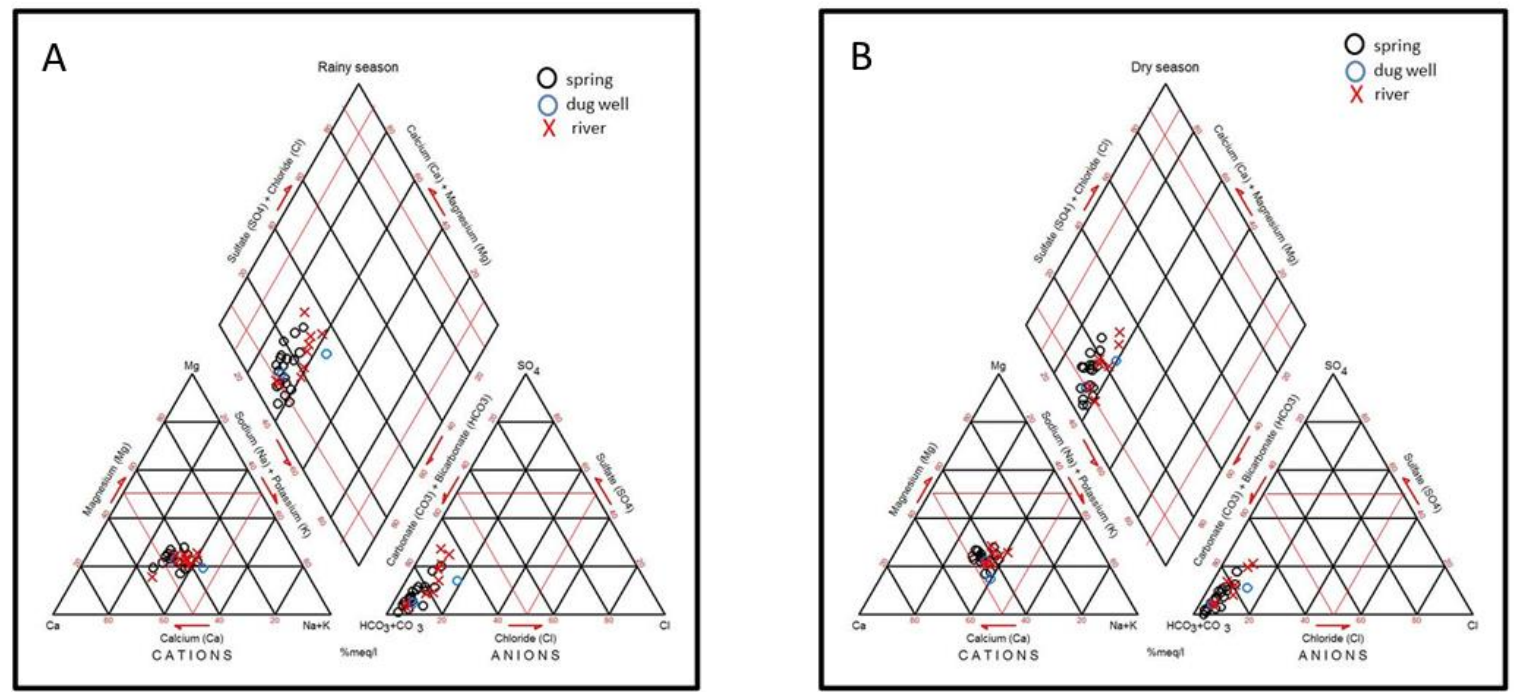

Figure 6. Piper diagram for rainy (A) and dry seasons (B) 


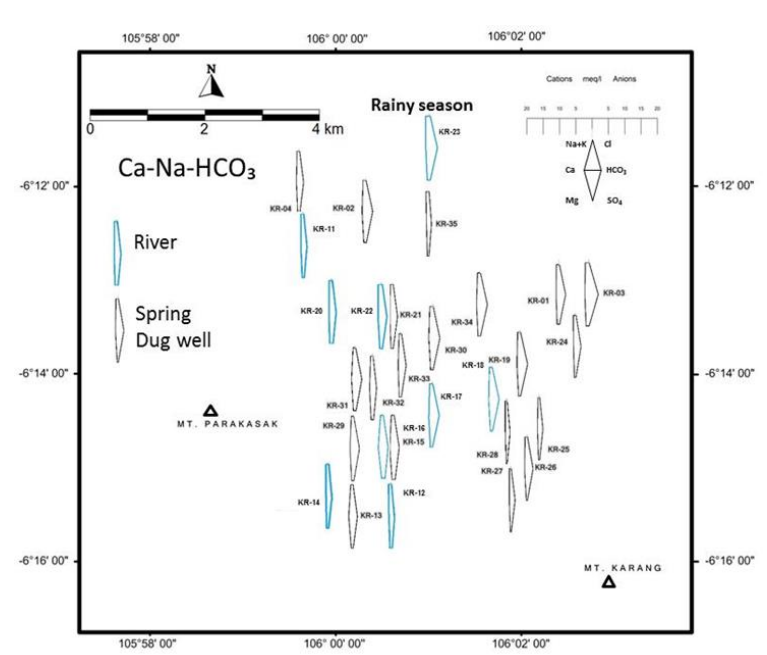

Figure 7A. Relative amount of major ions in spring, dug well and river samples plotted in stiff diagram in rainy season

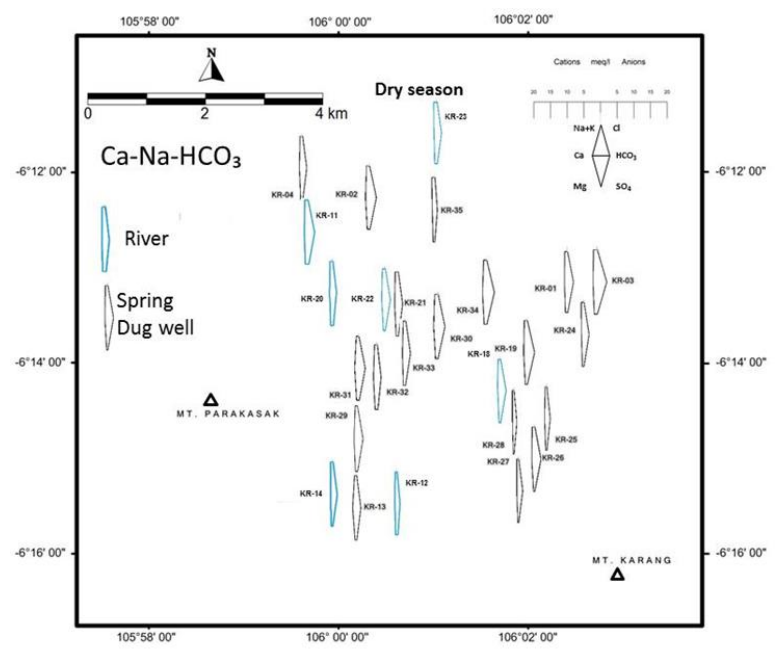

Figure 7B. Relative amount of major ions in spring, dug well and river samples plotted in stiff diagram in dry season

Tables 1 and 2 indicate that high $\mathrm{NO}_{3}$ concentrations were mostly found in the rainy season, while concentrations were mainly low in the dry season. This may be due to rainwater mixing with $\mathrm{NO}_{3}$ and percolating into the aquifer. High $\mathrm{NO}_{3}$ concentrations can be attributed to anthropogenic sources and are evidence that the aquifers in this area are vulnerable to contamination.

\subsection{Mineral and Water Interactions}

Figure 8 demonstrates mineral stability fields for weathering products and chemistry of the groundwaters; expressed as function of $\log \left(\left[\mathrm{Ca}^{2+}\right] /\left[\mathrm{H}^{+}\right]^{2}\right)$ and $\mathrm{SiO}_{2}$ in ppm (Tardy, 1971). Figure 8A shows that most of the water samples in rainy season were plotted close to the boundary of kaolinite and Ca-montmorillonite. However, in dry season the chemistries shift to a dominant field of Ca-montmorillonite (figure 8B). This is probably caused by less water amount in dry season. Although, the plots of rainy and dry season are close to the mineral boundary of kaolinite and Ca-montmorillonite, figure $8 \mathrm{~A}$ and $8 \mathrm{~B}$ suggests that kaolinisation by weathering is likely to be abundant in rainy season probably due to large water-rock ratios.

Such phenomenon is generally typical weathering products on the volcanic rocks from island of Hawaii (Berner, 1971). Moreover, it was implied that primary silicate mineral, such as albite, should be dissolved and weathered to montmorillonite in the groundwater systems, as shown in the equation below (Appelo \& Postma 2005);

$$
\begin{gathered}
3 \mathrm{Na}\left(\mathrm{AlSi}_{3}\right) \mathrm{O}^{8}+\mathrm{Mg}^{2+}+4 \mathrm{H}_{2} \mathrm{O} \longrightarrow 2 \mathrm{Na}_{0.5}\left(\mathrm{Al}_{1.5} \mathrm{Mg}_{0.5}\right) \mathrm{Si}_{4} \mathrm{O}_{10}(\mathrm{OH})_{2}+2 \mathrm{Na}^{+}+\mathrm{H}_{4} \mathrm{SiO}_{4} \\
\text { (Albite) }
\end{gathered}
$$

The alteration of albite to montmorillonite consumes no acid, but with kaolinite and gibbsite as weathering products, increasing amount of protons are consumed. Furthermore when albite alters to montmorillonite, $89 \%$ of the $\mathrm{Si}$ is preserved in the weathering product. This decreases to $33 \%$ for weathering to kaolinite and $0 \%$ for gibbsite (Appelo \& Postma, 2005).

Several water samples were plotted in the kaolinite field in the rainy season (Figure 8A) and one sample in dry season (Figure 8B). It indicated that the primary silicate minerals were dissolved and weathered to kaolinite in the groundwater systems, such as equation below:

$$
\begin{gathered}
2 \mathrm{Na}\left(\mathrm{AlSi}_{3}\right) \mathrm{O}_{8}+2 \mathrm{H}^{+}+9 \mathrm{H}_{2} \mathrm{O} \longrightarrow \mathrm{Al}_{2} \mathrm{Si}_{2} \mathrm{O}_{5}(\mathrm{OH})_{4}+2 \mathrm{Na}^{+}+4 \mathrm{H}_{4} \mathrm{SiO}_{4} \\
\text { (Albite) }
\end{gathered}
$$

The sequence of weathering products, going from montmorillonite over kaolinite to gibbsite, reflects increasing intensity of leaching, and removing silica and cation from the rock (Appelo and Postma, 2005). Dominance of Ca-montmorillonite indicates the excess of $\mathrm{Ca}^{2+}$ through weathering. Kaolinite is a common weathering product of feldspar and other silica (Oinam et al., 2012). 

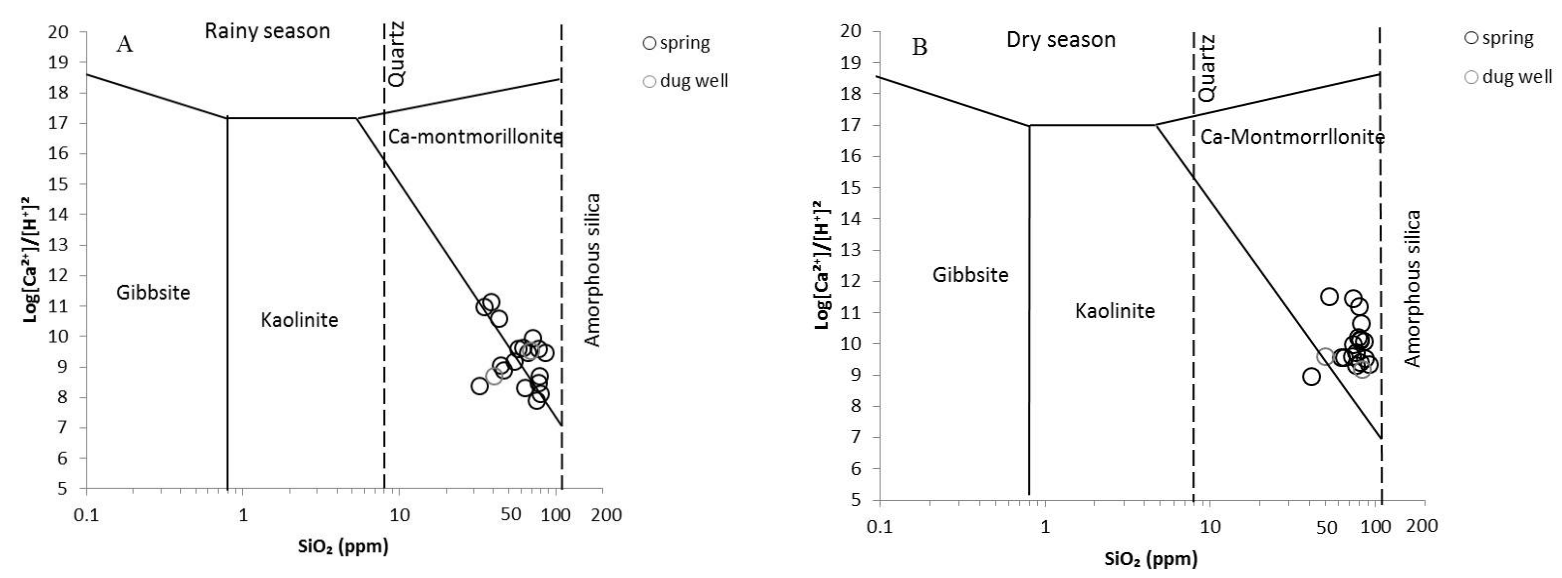

Figure 8 . The stability of anorthite and its possible weathering products gibbsite, kaolinite and Ca-montmorillonite (Tardy, 1971) in groundwater samples in rainy (A) and dry seasons (B)

The composition of the weathering residue depends on both hydrological conditions and the rate of mineral weathering. Montmorillonite is preferentially formed in relatively dry climates, where the rate of flushing of the soil is slow. Its formation is further enhanced when rapidly dissolving material such as volcanic rock is available (Appelo and Postma, 2005).

\subsection{Saturation Index}

Mineral equilibrium calculations are useful for predicting the presence of reactive minerals and estimating mineral reactivity in a groundwater system. By using the saturation index approach, it is possible to evaluate the degree of interaction between groundwater and minerals in the aquifer (Gemici and Filiz, 2001). The saturation index (SI) was used to investigate the thermodynamic controls on the water composition and was calculated using PHREEQC (Parkhurst and Appelo, 1999).

The relationship between $\mathrm{Na}^{+}$and $\mathrm{Ca}^{2+}$ concentrations and saturation indices with respect to anorthite and albite, respectively, in the rainy and dry seasons is shown in Figure 9. The SI values for anorthite and albite in water samples differed between the rainy and dry season; however, the SI values for gypsum were similar in the different seasons.
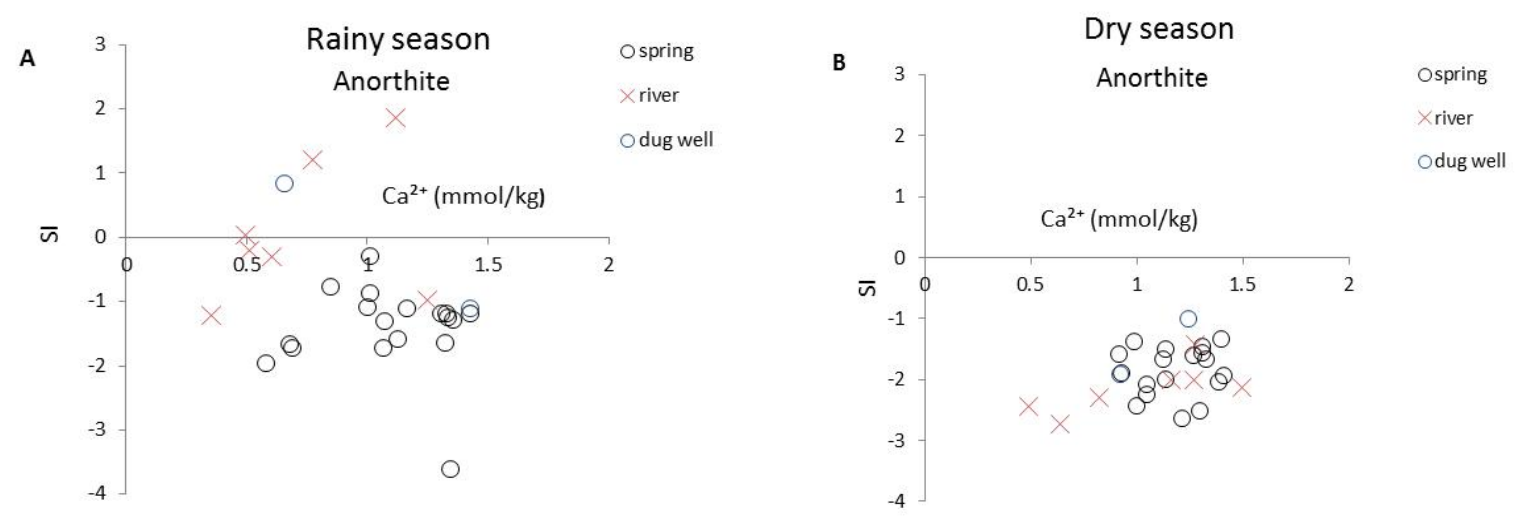

Figure 9a and 9b. Relationship between $\mathrm{Ca}^{2+}$ concentrations and saturation indices with respect to anorthite from spring, dug well and river samples in (A) rainy and (B) dry seasons 

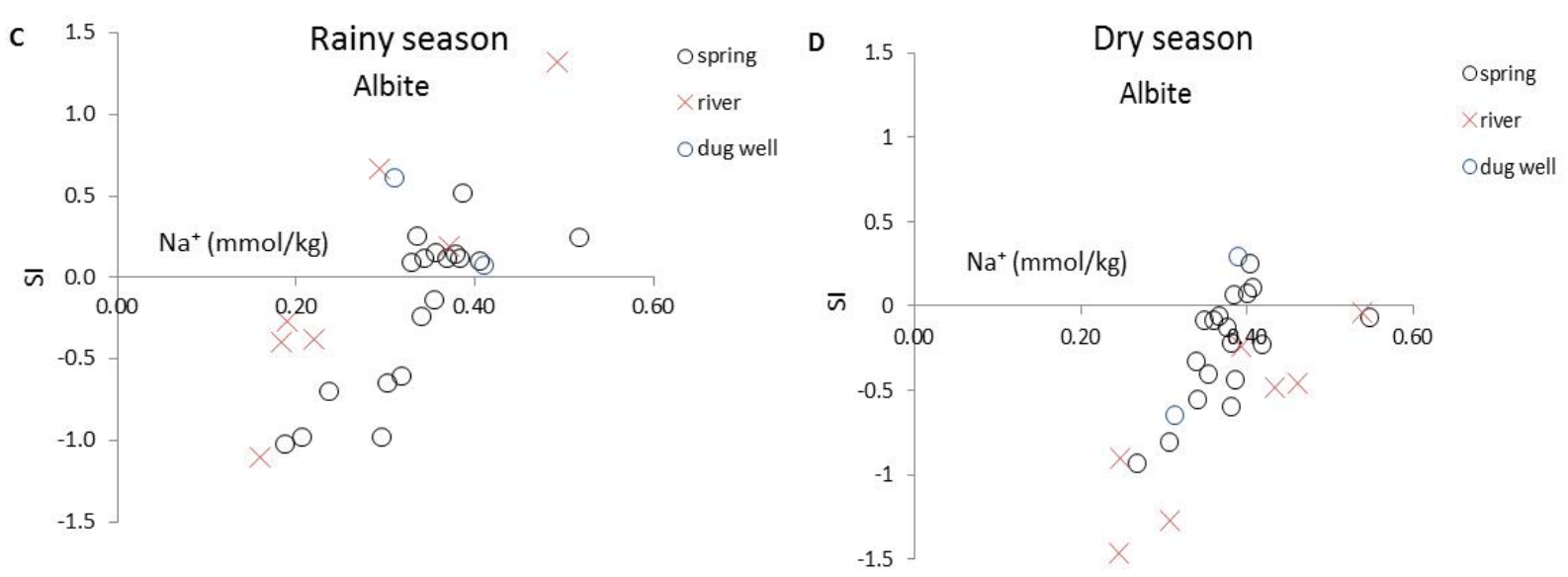

Figure 9c and 9d. Relationship between $\mathrm{Na}^{+}$concentrations and saturation indices with respect to albite from spring, dug well and river samples in (C) rainy and (D) dry seasons
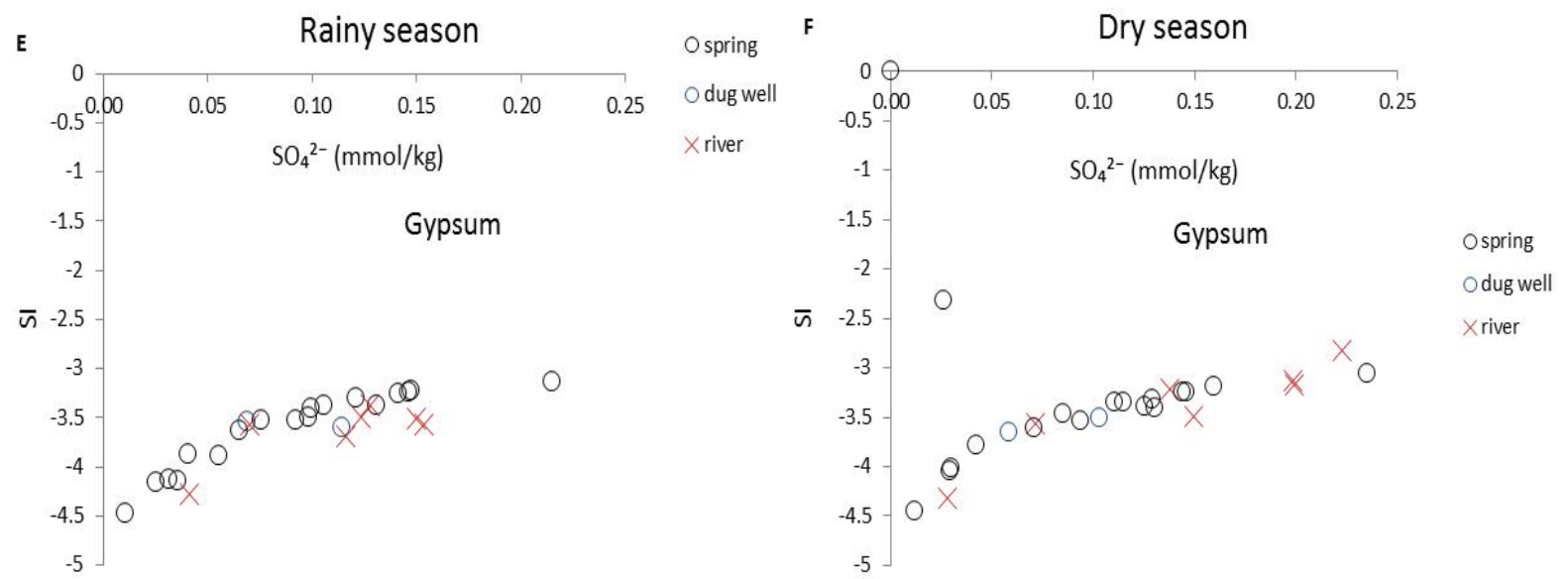

Figure 9e and 9f. Relationship between $\mathrm{SO}_{4}{ }^{2-}$ concentrations and saturation indices with respect to gypsum from spring, dug well and river samples in (E) rainy and (F) dry seasons

Water samples from springs, dug wells and rivers ranged from equilibrated to unsaturated with respect to anorthite (Figure 9a). However, one dug well and two river water samples were over-saturated with respect to anorthite. In contrast, all the water samples were unsaturated with respect to anorthite in the dry season (Figure 9b). Figure 9c demonstrates that, for albite, some of the water samples were closely equilibrated and over-saturated in the rainy season, while other samples ranged from being nearly equilibrated to unsaturated, which may be due to precipitation in this season. In the dry season, the majority of water samples were under-saturated with respect to albite, as shown in Figure 9d. Groundwater samples were between the SI values of gypsum and $\mathrm{SO}_{4}{ }^{2-}$ (Figure 9e and 9f). All groundwater samples were under-saturated for gypsum, indicating that $\mathrm{SO}_{4}{ }^{2-}$ dissolution is still taking place in the aquifers.

\subsection{Stable Isotopes of $\delta D$ and $\delta^{18} \mathrm{O}$}

Figure $10 \mathrm{a}$ and $10 \mathrm{~b}$ shows the relationship between the $\delta \mathrm{D}$ and $\delta^{18} \mathrm{O}$ isotope values in spring, dug well and river water samples for the rainy and dry seasons. 

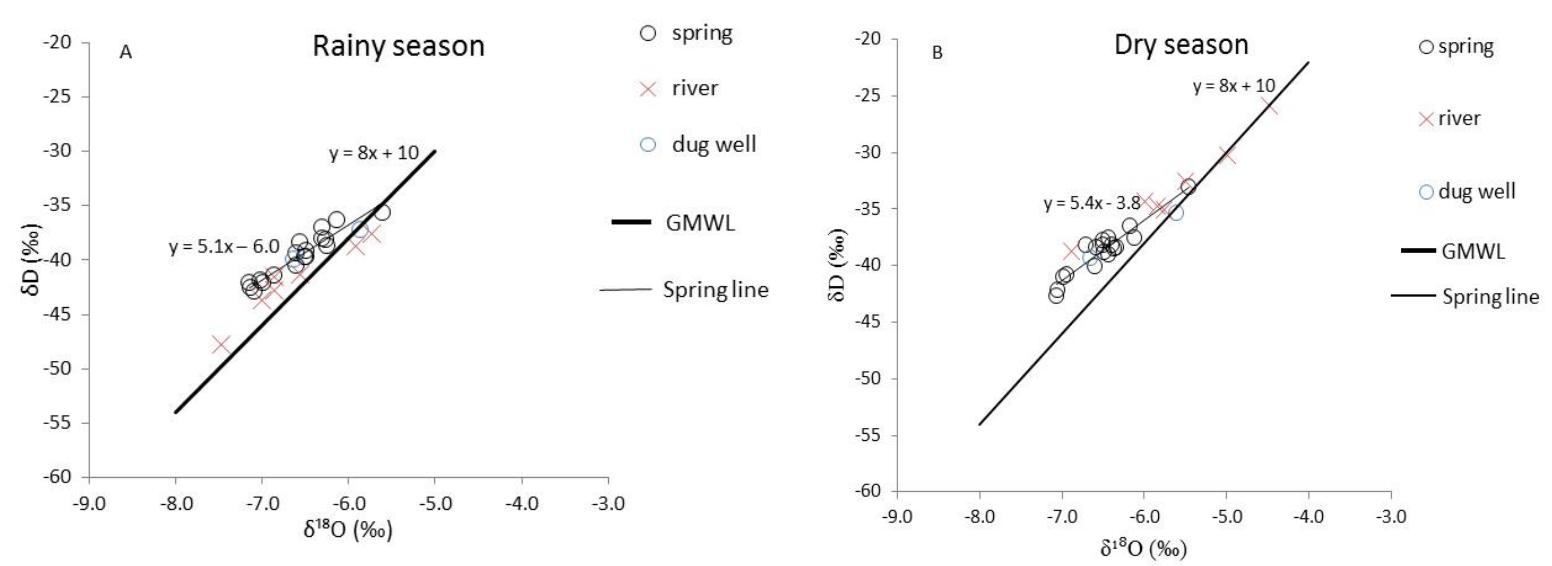

Figure $10 . \delta^{18} \mathrm{O}$ versus $\delta \mathrm{D}(\mathrm{A})$ in rainy and (B) dry seasons

The solid line in the figure indicates the Global Meteoric Water Line (GMWL). All the samples are plotted close to this line, implying that they are of meteoric water origin. This indicates that precipitation is the main source of groundwater recharge in this area. Furthermore, these figures also show the groundwater and river water samples lie on trajectories having a slope of about 5 . This implies that evaporation is a dominant factor lead to the enrichment of the isotope values.

Figure 11a and $11 \mathrm{~b}$ present the contour map of $\delta \mathrm{D}$ values of groundwater samples in the rainy and dry seasons, for which the interval contour values of $2 \%$. These figures also display trend direction of isotopic values are relative SE-NW and SW-NE in the slope of Mt. Karang. These directions may be due influenced by fault present in this area and topographical condition. Furthermore, in the northern foot of Mt. Parakasak the contour of isotopes values has relative W-E trend directions. Several water samples with light isotopes values were from the slopes of Mt. Karang, while heavy isotope values were found in samples from the slopes of Mt. Karang and Mt. Parakasak. The groundwater with light isotope values indicated the water is flowing in the deep aquifer and recharging at high elevation. Figure 12 shows the comparison of $\delta \mathrm{D}$ and $\delta^{18} \mathrm{O}$ values in the rainy and dry seasons. This figure also shows several water samples (KR-21, 24, 25, 27 and 35) experienced enrichment in the dry season relative to the rainy season. This is probably caused by evaporation. Most of the river water samples show enrichment in the dry season. During the rainy season, these rivers receive more amount of rainfall and evaporation processes occur. KR-21(spring) and KR-22 (river) establish an evidence that the samples were enriched due to evaporation.

On the other hand, most of the groundwater samples show unchanged isotopes values in both the seasons. This reflects these waters flowing along the season and based on the visual observation in the field, several springs (KR-1, 2, 3, 4A, 4C, 19 and 29) have a large discharge. 


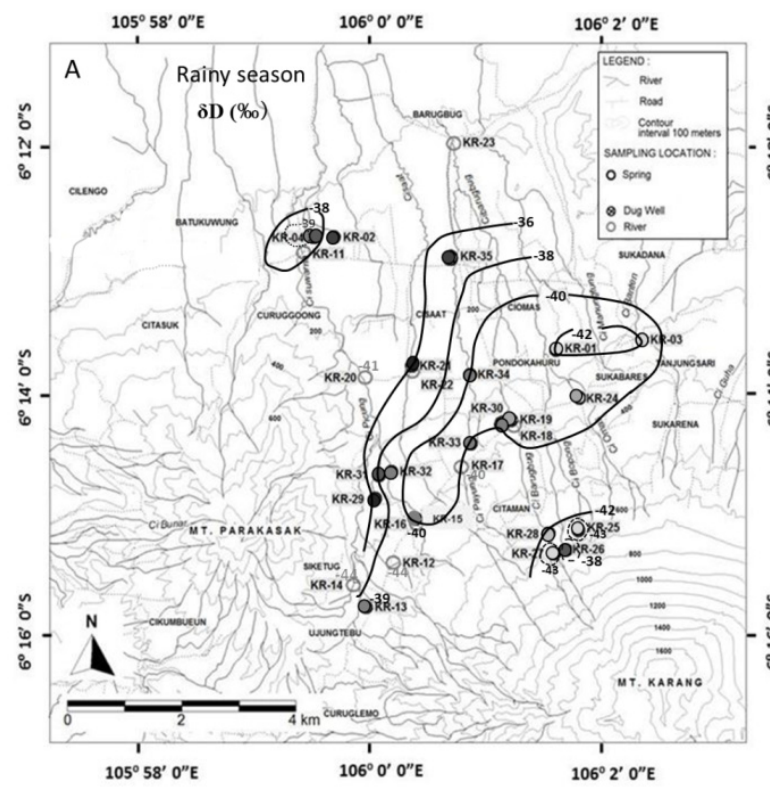

Figure 11A. Contour map of stable isotope $\delta \mathrm{D}$ values in rainy season.

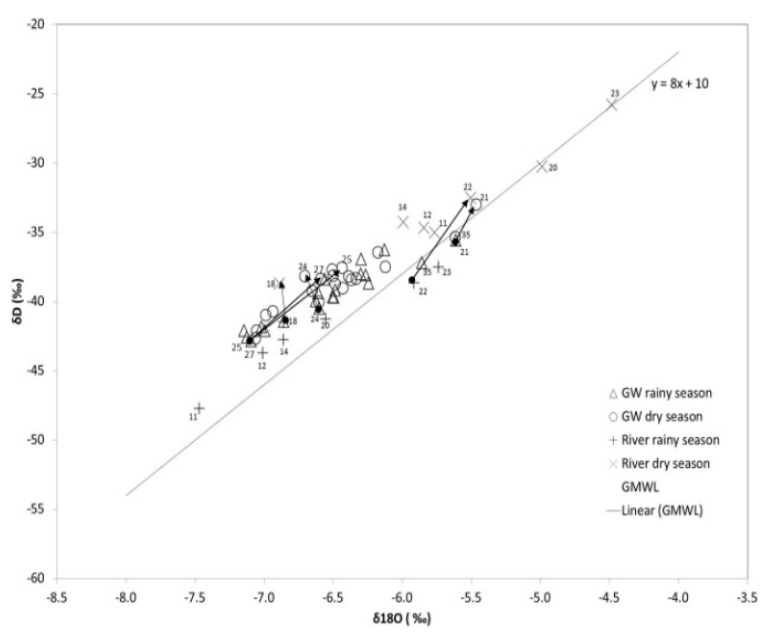

Figure $12 . \delta^{18} \mathrm{O}$ vs $\delta \mathrm{D}$ values in rainy and dry seasons for groundwater and river samples. The black arrows are representing the groundwater experiencing enrichment

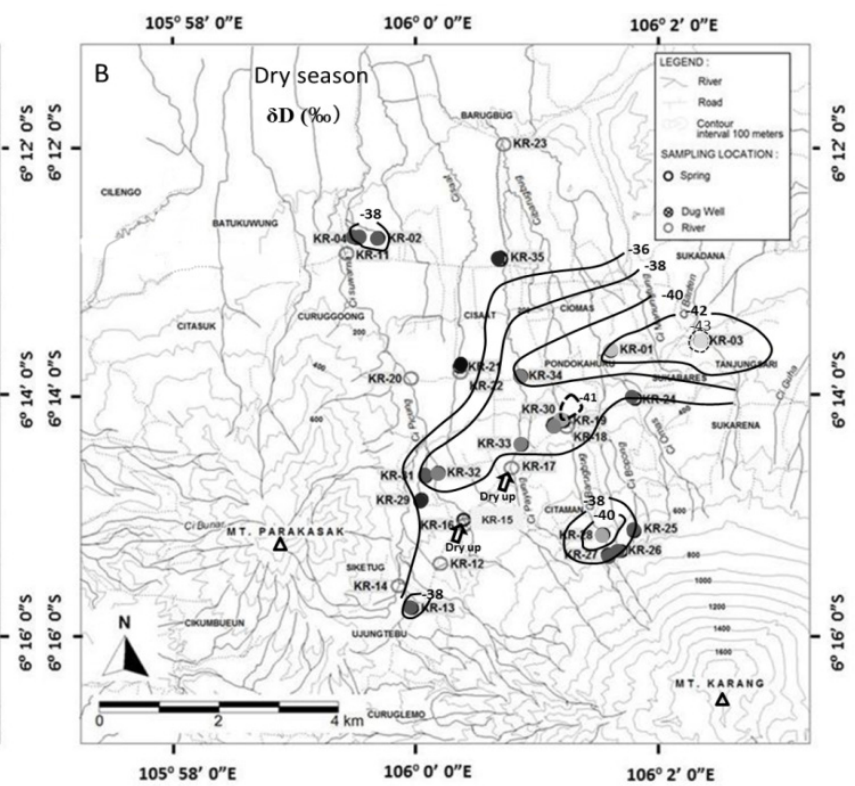

Figure 11B. Contour map of stable isotope $\delta \mathrm{D}$ values in dry season

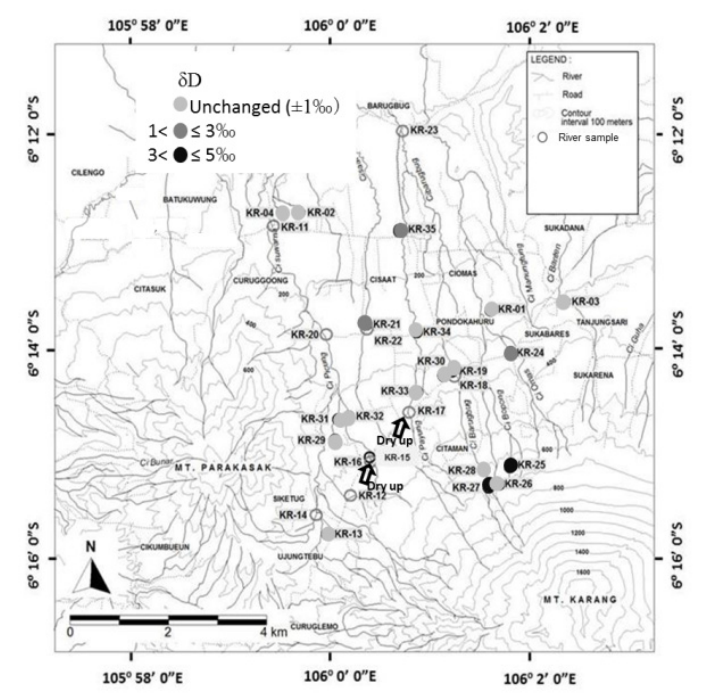

Figure 13. Degree of enrichment of $\delta \mathrm{D}$ values in groundwater samples

Degree of enrichment the isotope $\delta \mathrm{D}$ values and its distributions in rainy and dry seasons shown in figure 13 . Figure 13 shows, in particular, that several of the groundwater samples obtained from springs and dug well experienced enrichment in the rainy season when compared with the dry season; spring and dug well samples had $\delta \mathrm{D}$ values in the range of $2-5 \%$ (KR-21, 24, 25, 27 and KR-35). Isotopes were enriched in river water samples, and had values in the range of 3-12\%. The enrichment observed in the rainy season relative to the dry season is most likely due to evaporation that occurs during infiltration to the recharge area. Several groundwater samples (KR-13, 21, 24, 25, 26, 27, 29, 31 and KR-35) had heavy $\delta \mathrm{D}$ concentrations that had a range of $-38 \%$ to $-33 \%$ in the dry season, indicating that water mainly flowed in the shallow aquifers or unconfined aquifers and that the concentrations shifted in the different seasons.

\subsection{Recharge Mechanisms of the Volcanic Aquifer Systems}

A conceptual model of the recharge mechanism of the volcanic aquifer system in Mt. Karang is illustrated in 
Figure 14. The aquifer and groundwater flow systems within the Mt. Karang volcano are expressed by three profiles along cross sections indicated in Figure 1. There are two types of water isotopically; one is relatively deep circulated water with consistent $\delta \mathrm{D}$ values, the other is of shallow circulated one affected by evaporation.

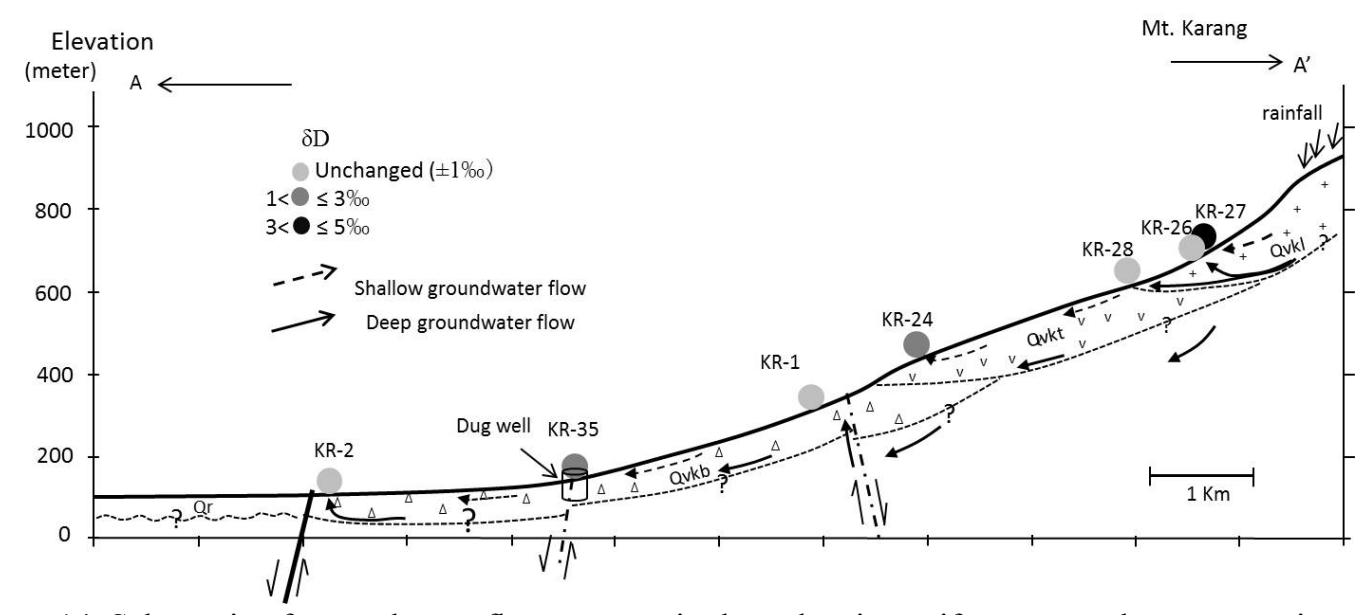

Figure 14. Schematic of groundwater flow systems in the volcanic aquifer system; the cross section refers to

Figure 1

The $\delta \mathrm{D}$ of KR-27 from local flow systems or shallow aquifers was $-38 \%$ o (see Figure 14) indicating that those waters mix with the evaporated surface water. KR-26 and KR-28 had $\delta \mathrm{D}$ of about -38 and $-41 \%$, respectively. The waters (KR-26 and 28) were unchanged in the different seasons or do not undergo evaporation processes. This implies that the water flows in the deep aquifers. However, enrichment of KR-24 in rainy season has been observed, indicating that the water mixes with the evaporated surface water.

The KR-1 had a different $\delta \mathrm{D}$ value $(-42 \%)$ and is observed to be stable in different seasons. It is inferred that the KR-1 has flowed through the deep aquifers and that evaporation process did not occur. On the other hand, KR-35 (dug well) has the heavy isotope $\delta \mathrm{D}$ of $-35 \%$, indicating that water flows in the very shallow aquifers and undergo evaporation.

KR-2 had $\delta$ D values ranging between $-38 \%$ to $-37 \%$ remain constant at different seasons. This suggests that the ground waters mix with the water from shallow aquifers and flows throughout the seasons.

\section{Conclusions}

In this study, we identified groundwater flow systems in the northern part of Mt. Karang and Mt. Parakasak by hydro-chemical and stable isotope composition analyses.

Generally, spring discharge occurs in the middle and foot slopes on the northern part of both volcanoes. The aquifer layers have distinct characteristics in terms of their fracture systems and porous media. The waters of the $\mathrm{Ca}-\mathrm{Na}-\mathrm{HCO}_{3}$ type from springs, dug wells and surface water did not change between the different seasons.

Conducted with the weathering product, most of the water samples in rainy season were plotted close to a boundary of kaolinite and Ca-montmorillonite. However, in dry season the chemistries shift to a dominant field of Ca-montmorillonite. This probably caused by less water amount in dry season.

Several water samples from springs, dug wells and rivers ranged from being nearly equilibrated to over-saturated with respect to the members of the plagioclase mineral (albite), which suggests that the water had adequate time to dissolve the mineral.

All water samples from the study area plotted close to the global meteoric water line, implying that their source was meteoric water. Several groundwater samples obtained from spring and dug well showed isotope concentration enrichment from the rainy to the dry season due to evaporation.

A conceptual model of recharge mechanisms in Mt. Karang has been reconstructed based on the hydrogeological, hydro-chemical and stable isotope data. There are two types of water isotopically; one is relatively deep circulated water with consistent $\delta \mathrm{D}$ values, the other is of shallow circulated one affected by evaporation. 


\section{Acknowledgments}

The authors thank the Faculty of Geology at the University of Padjadjaran and the Unpad team for their invaluable participation in this study. We would also like to acknowledge the Global-Center of Excellence in Novel Carbon Resource Sciences, Kyushu University for financial support for this work and the Directorate General Higher of Education National Ministry of Education Indonesia for a Scholarship Abroad.

\section{References}

Adi, S. (2003). Proposed soil and water conservation strategies for Lake Rawa Dano, West Java, Indonesia. IAHS issue no. 281 Water Resources Systems Hydrological Risk, Management and Development Symposium, Sapporo.

Appelo, C. A. J., \& Postma, D. (2005). Geochemistry, Groundwater and Pollution. Leiden, A.A: Balkema Publisher. http://dx.doi.org/10.1201/9781439833544

Bappeda \& BPS Kota Cilegon. (2011). Cilegon in figure 2011.

Berner, R. A. (1971). Principles of chemical sedimentology. McGraw-Hill New York, pp 240.

Bronto, S. (2006). Fasies gunungapi dan aplikasinya. Jurnal Geologi Indonesia, (2), 59-71 (In Indonesian).

Clark, I., \& Fritz, P. (1997). Environmental Isotopes in Hydrogeology. New York: Lewis Publishers.

D’Alessandro W., Federico, C., Longo, M., \& Parello, F. (2004). Oxygen isotope composition of natural waters in the Mt. Etna area. Journal of Hydrology, 296(1-4), 282-299. http://dx.doi.org/10.1016/j.jhydrol.2004.04.002

Dansgaard, W. (1964). Stable isotopes in precipitation. Tellus, (16), 436-468. http://dx.doi.org/10.1111/j.2153-3490.1964.tb00181.x

Delinom, R. (2009). Structural geology controls on groundwater flow; Lembang Fault case study, West Java, Indonesia. Hydrogeology Journal, 17(4), 1011-1023. http://dx.doi.org/ 10.1007/s10040-009-0453-z

Epsteins, S., \& Mayeda, T. (1953). Variations of the $\mathrm{O}^{18}$ content of waters from natural sources. Geochimica et Cosmochimica Acta, (4), 213-24. http://dx.doi.org/10.1016/0016-7037(53)90051-9

Garrels, R. M. (1967). Genesis of some ground waters from igneous rocks. Researches in Geochemistry, 2, John Wiley and Sons, Inc. p 405-420.

Gemici, U., \& Filiz, S. (2001). Hydrogeochemistry of the Cesme geothermal field in western Turkey. Journal of Volcanology and Geothermal Research, 110, 171-187. http://dx.doi.org/10.1016/S0377-0273(01)00202-5

Gonfiantini, R., Roche, M. A., Olivry, J. C., Fontes, J. C., \& Zuppi, G. M. (2001). The altitude effect on the isotopic composition of tropical rains. Chemical Geology, (181), 147-167. http://dx.doi.org/10.1016/S0009-2541(01)00279-0

Irawan, D. E., Puradimaja, D. J., Notosiswoyo, S., \& Soemintadiredja, P. (2009). Hydrogeochemistry of volcanic hydrogeology based on cluster analysis of Mount Ciremai, West Java, Indonesia. Journal of Hydrology, 376(1-2), 221-234. http://dx.doi.org/10.1016/j.jhydrol.2009.07.033

Jones, I. C., \& Banner, J. L. (2003). Estimating recharge thresholds in tropical karst island aquifers: Barbados, Puerto Rico and Guam. Journal of Hydrology, 278(1-4), 131-143. http://dx.doi.org/10.1016/S0022-1694 (03)00138-0

Kattan, Z. (1997). Environmental isotope study of the major karst springs in Damascus limestone aquifer systems: case of the Figeh and Barada springs. Journal of Hydrology, 193(1-4), 161-182. http://dx.doi.org/10.1016/S0022-1694(96)03137-X

Lee, K. S., Wenner, D. B., \& Lee, I. (1999). Using H and O isotopic data for estimating the relative contributions of rainy and dry season precipitation to groundwater: Example from Cheju Island, Korea. Journal of Hydrology, 222(1-4), 65-74. http://dx.doi.org/10.1016/S0022-1694(99)00099-2

Lubis, R. F., Sakura, Y., \& Delinom, R. (2008). Groundwater recharge and discharge processes in the Jakarta groundwater basin. Hydrogeology Journal, 16(5), 927-938. http://dx.doi.org/10.1007/s10040-008-0278-1

Oinam, J. D., Ramanathan, A. L., \& Singh, G. (2012). Geochemical and statistical evaluation of groundwater in Imphal and Thoubal district of Manipur, India. Journal of Asian Earth Sciences, (48), 136-149. http://dx.doi.org/10.1016/j.jseaes.2011.11.017

Parkhurst, D. L., \& Appelo, C. A. J. (1999). User's guide to PHREEQC (version 2)-a computer program for 
speciation, batch reaction, one-dimensional transport, and inverse geochemichal calculations. U.S. Geological Survey Water Resources Investigation Report, 99-4259, 312.

Rusmana, E., Suwitodirdjo, K., \& Suharsono. (1991). Geology of the Serang Quadrangle, Jawa, 1: 100,000. Bandung: Geological research and development centre.

Santosa, S. (1991). Geology of the Anyer Quadrangle, West Jawa, 1:100,000. Bandung: Geological Research and Development Centre.

Scholl, M. A., Gingerich, S. B., \& Tribble, G. W. (2002). The influence of microclimates and fog on stable isotope signatures used in interpretation of regional hydrology: East Maui, Hawaii. Journal of Hydrology, 264(1-4), 170-184. http://dx.doi.org/10.1016/S0022-1694(02)00073-2

Sudibyo, Y., Takmat, U., \& Sunarya, Y. (1995). Peta Hidrogeologi Indonesia, 1:100,000. Lembar 1109-6 \& 1110-3 Serang. Bandung: Direktorat Geologi Tata Lingkungan (In Indonesian).

Suryaman, M. (1999). Peta Hidrogeologi Indonesia, 1:100.000 Lembar 1110-2 \& 1109-2 Anyer. Bandung: Direktorat Geologi Tata Lingkungan (In Indonesian).

Syariman, P., \& Hendarmawan. (2010). Analisis fenomena kehilangan air sungai Cisuwarna. Jurnal Teknik Hidraulik, 1(1) (In Indonesian).

Tardy, Y. (1971). Characterization of the principal weathering types by the geochemistry of waters from European and African crystalline massifs. Chemical Geology, (7), 253-271. http://dx.doi.org/10.1016/0009-2541(71)90011-8

Van Bemmelen, R. W. (1949). The geology of Indonesia. Vol.1A. The Hague: Government Printing Office.

\section{Copyrights}

Copyright for this article is retained by the author(s), with first publication rights granted to the journal.

This is an open-access article distributed under the terms and conditions of the Creative Commons Attribution license (http://creativecommons.org/licenses/by/3.0/). 